CYTOLOGICAL METHODS FOR THE DETECTION, IDENTIFICATION, AND CHARACTERIZATION OF ORCHID VIRUSES AND THEIR INCLUSION BODIES

\author{
By \\ NAN-JING KO
}

A DISSERTATION PRESENTED TO THE GRADUATE SCHOOL OF THE UNIVERSITY OF FLORIDA IN PARTIAL FULFILLMENT OF THE REQUIREMENTS FOR THE DEGREE OF DOCTOR OF PHILOSOPHY

UNIVERSITY OF FLORIDA

1985 
This dissertation is dedicated to my mother, Min-Chu Ko.

$$
\text { 謹此 }
$$

南犬给我敬爱的母親 
ACKNOWLEDGMENTS

I wish to express my sincere gratitude to Drs. J. R. Edwardson and F. W. Zettler whose guidance, encouragement, and friendship made the fulfillment of my educational aspirations real.

Special thanks are due to Mr. R. G. Christie and to Drs. E. Hiebert, D. E. Purcifull, H. C. Aldrich and T. J. Sheehan for their guidance and helpful suggestions in the preparation of this dissertation.

Appreciation is also extended to Mr. S. Christie, Mr. W. Crawford, Ms. G. C. Wisler, Mr. C.-A. Chang, Ms. A. E. Logan, Mr. M. S. Elliott and Ms. C. A. Baker for their generous assistance during the course of this investigation. I am also grateful to Dr. G. Erdos of the Microbiology and Cell Science Department for technical assistance in immunogold labelling and for supplying protein A-gold.

I am indebted to my family for their moral and financial support and especially to my wife for her help and companionship and to my brothers for taking care of my mother throughout these years.

Appreciation is also expressed to the National Science Council of the Republic of China and to the American Orchid Society. 
TABLE OF CONTENTS

$\underline{\text { Pace }}$

ACKNOWLEDGEMENTS. . . . . . . . . . . . . . . . iii

ABSTRACT. . . . . . . . . . . . . . . vi

CHAPTERS

1 INTRODUCTION. • . • . . . . . . . . . . 1

2 USE OF LIGHT MICROSCOPY TO DETECT AND

DIAGNOSE ORCHID VIRUSES . . . . . . . . . 5

Introduction . . . . . . . . . . . . 5

Materials and Methods . . . . . . . . 6

Results... . . . . . . . . . . . . 10

Odontoglossum Ringspot Virus. . . . . . 10

Cymbidium Mosaic Virus. . . . . . . . . 15

Cucumber Mosaic Virus . . . . . . . . 18

Bean Yellow Mosaic Virus. . . . . . . 22

Uncharacterized Bacilliform Virus . . . . 25

Discussion. . . . . . . . . . . . 29

3 CONFIRMATORY STUDIES OF LIGHT MICROSCOPE

OBSERVATIONS. . . . . . . . . . . . . . 33

Introduction. . . . . . . . . . . . 33

Materials and Methods.......... . 34

Leaf Dips................ . 34

Thin Sectioning. . . . . . . . . . . 35

Immunofluorescence Microscopy . . . . . 36

Protein A-Gold Labelling. . . . . . . . . 37

Results . . . . . . . . . . . . . . 38

VaMo Negative Staining. . . . . . . . . 38

Thin Sectioning. . . . . . . . . . . 39

Immunofluorescence Microscopy . . . . . . 43

Protein A-Gold Labelling. . . . . . . . 50

Discussion. . . . . . . . . . . . 56

4 CONCLUSIONS . . . . . . . . . . 62 
APPENDICES

I A SIMPLIFIED BIOASSAY TECHNIQUE FOR CYMBIDIUM MOSAIC AND ODONTOGLOSSUM RINGSPOT VIRUSES • . 66

II AN EFFICIENT PROCEDURE FOR STAINING LARGE NUMBERS OF ELECTRON MICROSCOPIC GRIDS . . . . 70

II COMPARATIVE DIAGNOSES OF ORCHID VIRUSES BY LIGHT MICROSCOPY, ELECTRON MICROSCOPY, AND SEROLOGY. . . . . . . . . . . . . 73

LITERATURE CITED. • • • • • • • • • • • • • . . 75

BIOGRAPHICAL SKETCH • . . . . . . . . . . . . 83 
Abstract of Dissertation Presented to the Graduate School of the University of Florida in Partial Fulfillment of the Requirements for the Degree of Doctor of Philosophy

\section{CYTOLOGICAL METHODS FOR THE DETECTION, IDENTIFICATION, AND CHARACTERIZATION OF ORCHID VIRUSES AND THEIR INCLUSION BODIES}

\section{By}

$$
\text { Nan-Jing Ko }
$$

$$
\text { May } 1985
$$

Chairman: F. W. Zettler Cochairman: J. R. Edwardson

Major Department: Plant Pathology

Light microscopy was explored for detecting and diagnosing orchid viruses. Bioassay, serology and electron microscopy have all been used for viral detection, but most studies have involved only Cymbidium mosaic and odontoglossum ringspot viruses. The other orchid viruses are not well-characterized and practical means for their diagnoses in orchids have not been developed. In this investigation, light microscopic techniques were developed and their diagnostic potential was assessed. Calcomine orange-Luxol brilliant green (O/G) combination and Azure A were used for selective staining of proteinaceous inclusions and inclusions containing nucleoprotein, respectively. Six viruses were studied, Cymbidium mosaic (CYMV), Odontoglossum ringspot (ORSV), bean yellow mosaic (BYMV), cucumber mosaic (CMV), and two uncharacterized bacilliform viruses. Other techniques were used to verify the light microscopic results. These included 
immunofluorescence microscopy, immunogold labelling, and conventional electron microscopy (leaf dips and ultrathin sectioning). The preparation of ultrathin sections was facilitated considerably by the development of a device for simultaneous staining of 10 or more grids.

Banded and crescent shaped inclusions were found in CyMVinfected tissues stained with Azure A. Paracrystalline and stacked-plate inclusions were formed in the ORSV-infected tissues stained with either $O / G$ combination or Azure $A$. In CMV-infected tissues stained with Azure A, angular crystals with or without clear centers were found. Cytoplasmic cylindrical inclusions were observed in the BYMV-infected tissues stained with the $\mathrm{O} / \mathrm{G}$ combination. Nuclear inclusions occurred in the bacilliform virus-infected tissues stained with either the Azure $A$ or $O / G$ combination.

Direct fluorescence microscopy confirmed the presence of viral-related agents in the CYMV-, ORSV- and CMV-infected tissues. Vanadyl molybdate-phosphotungstate (VaMo) negative staining was used for confirming the presence of CyMV and ORSV. Protein A-gold labelling was applied to identify CyMV, ORSV, BYMV and CMV in the thin sections of tissues embedded in LR White resin.

Light microscopy was demonstrated to be a useful diagnostic tool for orchid viruses. The diagnoses by light microscopy were confirmed by Vamo negative staining, thin sectioning, immunofluorescence microscopy and protein A-gold labelling. 


\section{CHAPTER 1 \\ INTRODUCTION}

Orchidaceae is one of the largest and most diverse families of plants. It includes 7-10\% of all flowering plant species (Dressler, 1981). Orchids are widely grown throughout the world for sale as cut flowers or as potted plants. The value of an individual mature plant can range from a few dollars to several thousand dollars. In Florida, orchid production has been estimated to have an annual sale value of three million dollars (Anonymous, 1983), while the Federal Republic of Germany imported $\$ 22.9$ million of fresh-cut orchids (Anonymous, 1978).

The value of individual orchids is reduced considerably by plant pathogenic infections. Viruses are particularly problematic in orchids wherever they are grown. The most serious damage occurs when symptoms become evident on the flowers. Twenty-two viruses have been reported in orchids (Lawson and Horst, 1984). Cymbidium mosaic (CYMV) and Odontoglossum ringspot (ORSV) viruses, the first orchid viruses to be described, are the most prevalent. Many of the other viruses of orchids have only recently been described and have not been well-characterized. The prevalence of viruses in 
orchids, particularly CyMV and ORSV, is presumably due to three factors: i) some are readily transmitted by contaminated cutting tools used during propagation and flower harvesting; ii) the genetic diversity of the orchidaceae results in variable symptom expression and therefore symptoms are unreliable as a means of diagnosis (Sheehan, 1980); and iii) the viruses have been widely distributed through the international exchange of individual plants.

Bioassay and electron microscopical and serological techniques have been used previously for detecting and diagnosing some orchid viruses (Lawson and Ali, 1975; Lawson and Horst, 1984; Inouye, 1977; Lawson and Brannigan, in press; Wisler et al., 1982). For CYMV, ORSV, and certain other orchid viruses, these methods have proven to be reliable and practical. Certain bioassay and serological techniques have been modified specifically for orchids (Appendix I; wisler et al., 1982). However, such methods are not applicable for most of the other orchid viruses Iisted by Lawson and Horst (1984). This limitation is likely to be very significant to the orchid industry, especially as some viruses have aerial vectors and can spread rapidly in collections. Bioassays by manual inoculation are not applicable to viruses such as the Masdevallia isometric and Cypripedium filamentous viruses which are apparently not transmissible by this means. Likewise, serological techniques cannot be applied to any of the rhabdoviruses for which antisera are not yet available. 
Electron microscopy of negatively stained samples also has Iimitations, particularly for isometric viruses such as Cymbidium ringspot and/or cucumber mosaic viruses which have similar particle morphologies. Electron microscopy of thin sections is not also applicable for routine diagnosis due to the time, labor, and expense involved in processing samples. The purpose of this study was to explore the potential of light microscopy as a method for detecting and diagnosing orchid viruses. Immunofluorescence microscopy, protein A-gold labelling, VaMo negative staining, thin sectioning, immunodiffusion and slicing bioassay (Appendix I) techniques were used to verify the results of light microscopic diagnoses. Christie and Edwardson (1977) have described light microscopic techniques as being very useful for diagnosing plant viruses at the group level and, in some instances, at the specific level. This system has also been shown to be useful for diagnosis of viruses infecting certain crops, such as peppers (Edwardson and Christie, 1979). The low cost of the basic equipment and the relatively short time involved in processing samples are some advantages of light microscopy. However, certain limitations must be overcome before it can be applied to crops such as orchids. Unlike many herbaceous plants, such as peppers, most orchid leaves are thick and leathery, and previously described techniques, such as epidermal peels (Hiebert et al., 1984), are difficult to obtain. For orchids, therefore, special modifications must be 
developed. A second important problem to overcome is the lack of background information about orchid viruses, most of which are poorly characterized. Indeed, of the 22 viruses listed by Lawson and Horst (1984), only 12 viruses have been assigned to virus groups by the International Committee for the Taxonomy of Viruses (ICTV) (Matthews, 1982). Finally, the resolution limitations of light microscopy makes confirmation by other means necessary regarding the characterization of some of the inclusions observed. The lack of such information, especially for orchid viruses, makes such studies a necessary contingency for this type of investigation. 
CHAPTER 2

USE OF LIGHT MICROSCOPY TO DETECT AND DIAGNOSE

ORCHID VIRUSES

\section{Introduction}

Odontoglossum ringspot (ORSV) and Cymbidium mosaic (CyMV) are the best characterized orchid viruses, and several reliable bioassay and electron microscopical and serological techniques for their detection have already been developed (Appendix I, Corbett, 1974; Inouye, 1977; Lawson and Ali, 1975; Lawson and Brannigan, in press; Wisler et al., 1982). Since the discovery of these two viruses, at least 20 additional orchid viruses have been reported, some of which induce debilitating diseases (Lawson and Horst, 1984; Lawson and Brannigan, in press). However, only 12 of these viruses are sufficiently characterized to be assigned to groups by the International Committee for the Taxonomy of Viruses (Matthews, 1982). This deficiency of information can be attributed in part to a lack of convenient diagnostic techniques, which is especially true for those viruses that are not manually transmissible and for which antisera have not been prepared.

Light microscopy is useful for diagnosing viruses representing 16 of the 28 recognized virus groups (Matthews, 
1982) based on the inclusions they induce (Christie and Edwardson, 1977; Edwardson and Christie, 1978; Hamilton et al.., 1981). This study explores the applicability of the light microscope for diagnosing orchid viruses, as was done previously for pepper viruses (Edwardson and Christie, 1979). Electron microscopy of the inclusions found by light microscopy was conducted to reveal the fine structure of the inclusions.

\section{Materials and Methods}

Among the genera and viruses (in parentheses) studied in this investigation were: Brassia (uncharacterized bacilliform virus), Cattleya (ORSV, CyMV), Cymbidium (ORSV, CyMV, uncharacterized bacilliform virus), Masdevallia (bean yellow mosaic virus), Phalaenopsis (ORSV, CYMV, cucumber mosaic virus), and Vanilla (CyMV). For each plant tested, an unopened new leaf and the first and second mature leaves (with or without evidence of symptoms) were used.

The Azure A and the calcomine orange/Luxol brilliant green stain combinations (O/G) were used (Christie and Edwardson, 1977; Hiebert et al., 1984) for light microscopic examination of viral inclusion bodies. The thick texture of most orchid leaves precluded removal of epidermal strips for staining. To overcome this problem, the following modifications were employed: I) For thin-leaved orchids (e.g., Phaius), leaf 
pieces (ca. $0.5 \times 3.0 \mathrm{~cm}$ ) were cut, laid upon glass slides, and gently rubbed with 320 grit sandpaper first and then 600 grit sandpaper (cut into 1 x $4 \mathrm{~cm}$ pieces) to remove the cuticle and permit stain penetration. Using this technique, it was possible to remove enough overlying tissues to reveal the epidermal layers below those being abraded. 2 ) For thickerleaved orchids such as Cattleya, tissues were sliced paradermally or longitudinally with razor blades. Paradermal sections were obtained by cutting leaves parallel to the leaf surface (Fig. 1), while longitudinal sections were obtained by inserting leaf tissues in either styrofoam or pith as a support while they were being sectioned.

The thick-walled tissues infected with ORSV were stained with the O/G combination at room temperature for 10 minutes and then heated at $60^{\circ} \mathrm{C}$ for another 5 minutes. Leaves with thinwalled cells were stained in the $O / G$ combination at room temperature for 15 minutes. In some instances, CyMv-infected tissues were fixed in 5\% glutaraldehyde (in 0.1 M sodium. phosphate, pH 7.0) for two hours and then rinsed with the same buffer to preserve inclusion fine structure. For the bacilliform viruses, paradermal strips were first treated with either 5\% Triton X-100 for 5 minutes or $1 \%$ Triton X-100 for 10 minutes followed by staining in Azure $\mathrm{A}$ at $60^{\circ} \mathrm{C}$ for 10 minutes.

Comparable tissues were also examined by electron microscopy to confirm the light microscopic observations. Tissues were fixed for thin sectioning in 5\% glutaraldehyde, 


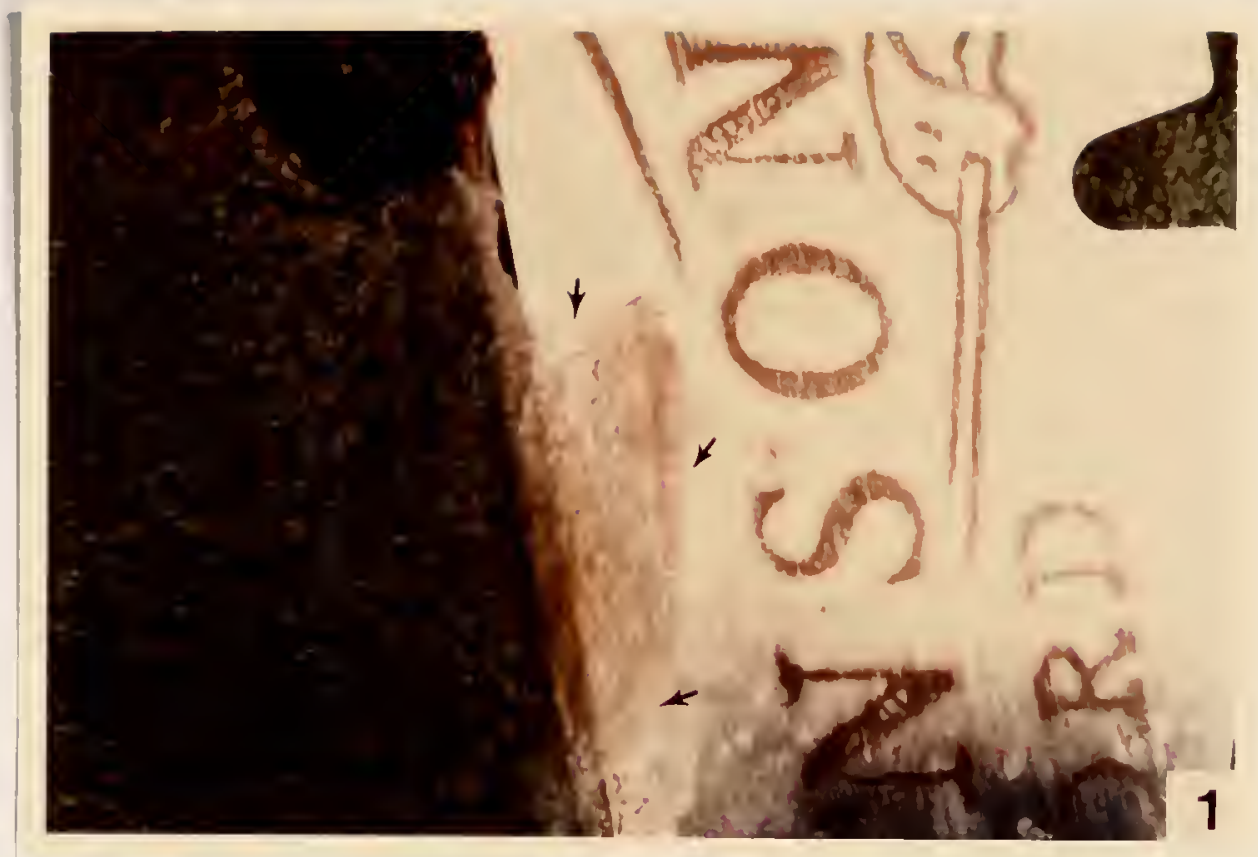

Figure 1. Paradermal section (arrows) of Cattleya showing the thickness of tissue to be cut with a razor blade for staining. 
postfixed in $1-2 \% \mathrm{OsO}_{4}$, dehydrated with acidified 2,2dimethoxypropane (Muller and Jacks, 1975), and embedded in Spurr's low-viscosity medium (Spurr, 1969). Sections were made with either a glass or a diamond knife and were stained with potassium permanganate, uranyl acetate, and lead citrate (Ko and Chen, 1982).

The identities of ORSV, CYMV, bean yellow mosaic virus (BYMV), and cucumber mosaic virus (CMV) were confirmed in tests using antisera to the respective viruses. Expressed sap was tested against antisera to the respective viruses in sodium dodecyl sulfate (SDS) double radial immunodiffusion tests as described previously (Purcifull and Batchelor, 1977; Zettler et al., 1978; Kuwite and Purcifull, 1982; Wisler et al., 1982). The immunodiffusion medium used contained $0.5 \%$ SDS, $1 \% \mathrm{NaN}_{3}$ ' $0.8 \%$ Noble agar. Slicing bioassays were used to identify the CYMV and ORSV on the indicator hosts, Cassia occidentalis and Gomphrena globosa, respectively (Appendix I). Conventional bioassay techniques (Lawson and Brannigan, in press) were used for CMV and BYMV. Cucumber mosaic virus infections were confirmed by inoculation of several hosts, including cucumber (Cucumis sativus "Marketer"), tomato (Lycopersicon esculentum), Nicotiana benthamiana, N. x edwardsonii, N. glutinosa, N. tabacum Xanthi nc., cowpea (Vigna unguiculata), and V. radiata. Bean yellow mosaic virus infections were confirmed by 
inoculation of peas (Pisum sativum 'Alaska', 'Ranger', and 'Little Marvel') and $\mathrm{N}$. benthamiana.

Freshly sectioned orchid tissues were exposed to antisera (refer to chapter 3) conjugated with tetramethyl rhodamine isothiocyanate (TRITC), and were examined for virus-induced inclusions with a Nikon Fluophot fluorescence microscope (Hiebert et al. , 1984).

\section{$\underline{\text { Results }}$}

Odontoglossum Ringspot Virus

Crystalline stacked plate and paracrystalline inclusions typical of ORSV and some other tobamoviruses (Christie and Edwardson, 1977; Edwardson and Zettler, in press) were readily observed by light microscopy in epidermal and mesophyll tissues of infected plants (Figs. 2 and 3 ). These inclusions are aggregations of virus particles (Figs. 4 and 5), as determined by electron microscopy of thin sections.

Thick-walled tissues required prestaining at room temperature for 10 minutes followed by heating at $60^{\circ} \mathrm{C}$ for 5 minutes to achieve stain penetration. Treatment with the $\mathrm{O} / \mathrm{G}$ combination without heat resulted in poor staining of inclusions (Fig. 6). Tissues were stained with Azure A for 1520 minutes at $60^{\circ} \mathrm{C}$ to detect the nucleic acid in inclusions. These inclusions were stained reddish-violet (Figs. 8 and 9), but they did not stain with Azure A at room temperature (Fig. 7). Heat treatment $\left(60^{\circ} \mathrm{C}\right.$ for $1-2$ minutes) has also been shown to be necessary for staining crystalline, paracrystalline, angled-layered-aggregate and fibrous mass inclusions of other 


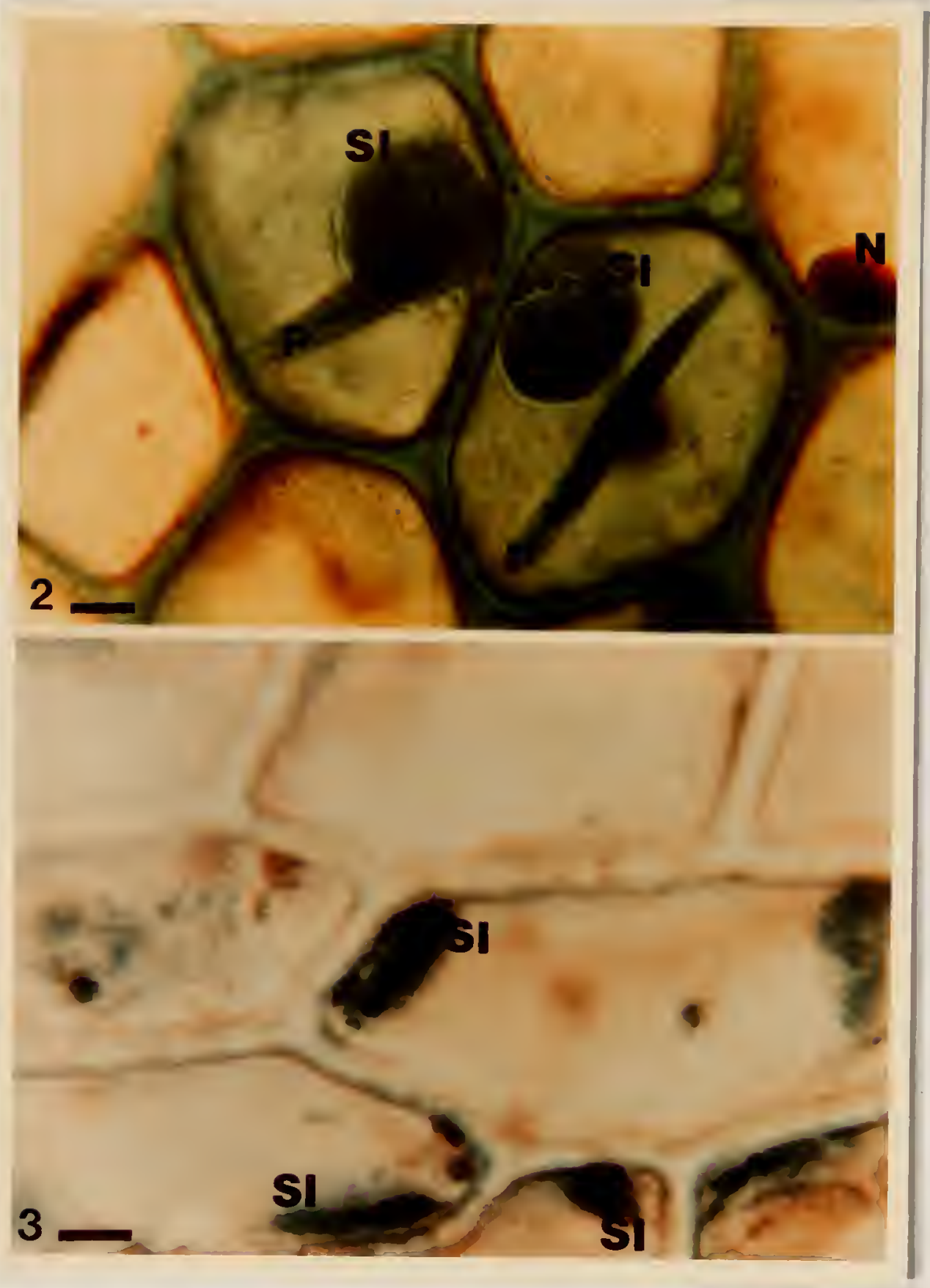

Figure 2. Light micrograph of paracrystals (P) and polar view of stacked-plate inclusions (SI) of ORSV-infected Cattleya leaf cells stained with O/G combination. N: Nucleus. Bar $=2$ um.

Figure 3. Light micrograph showing side view of stacked-plate inclusion (SI) in ORSVinfected Cymbidium leaf cells stained with $\mathrm{O} / \mathrm{G}$ combination. Bar $=5 \mathrm{\mu m}$. 


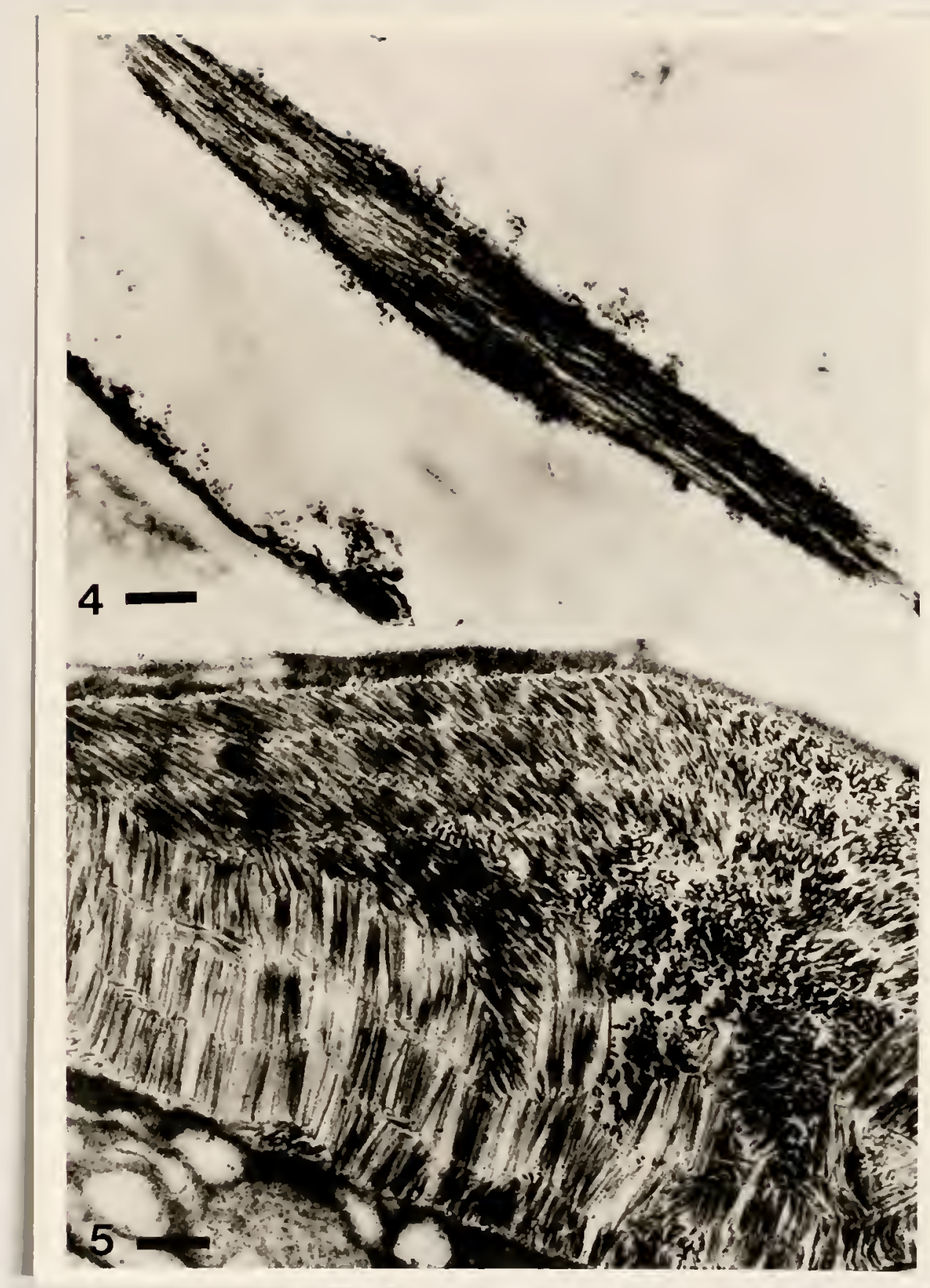
Figure 4. Electron micrograph of a portion of paracrystal induced by ORSV in Cattleya leaf mesophyll cell. Bar $=400 \mathrm{~nm}$.

Figure 5. Electron micrograph of a portion of stacked-plate inclusions induced by ORST in Cattleya leaf mesophyll cell. Bar $=300 \mathrm{~nm}$. 

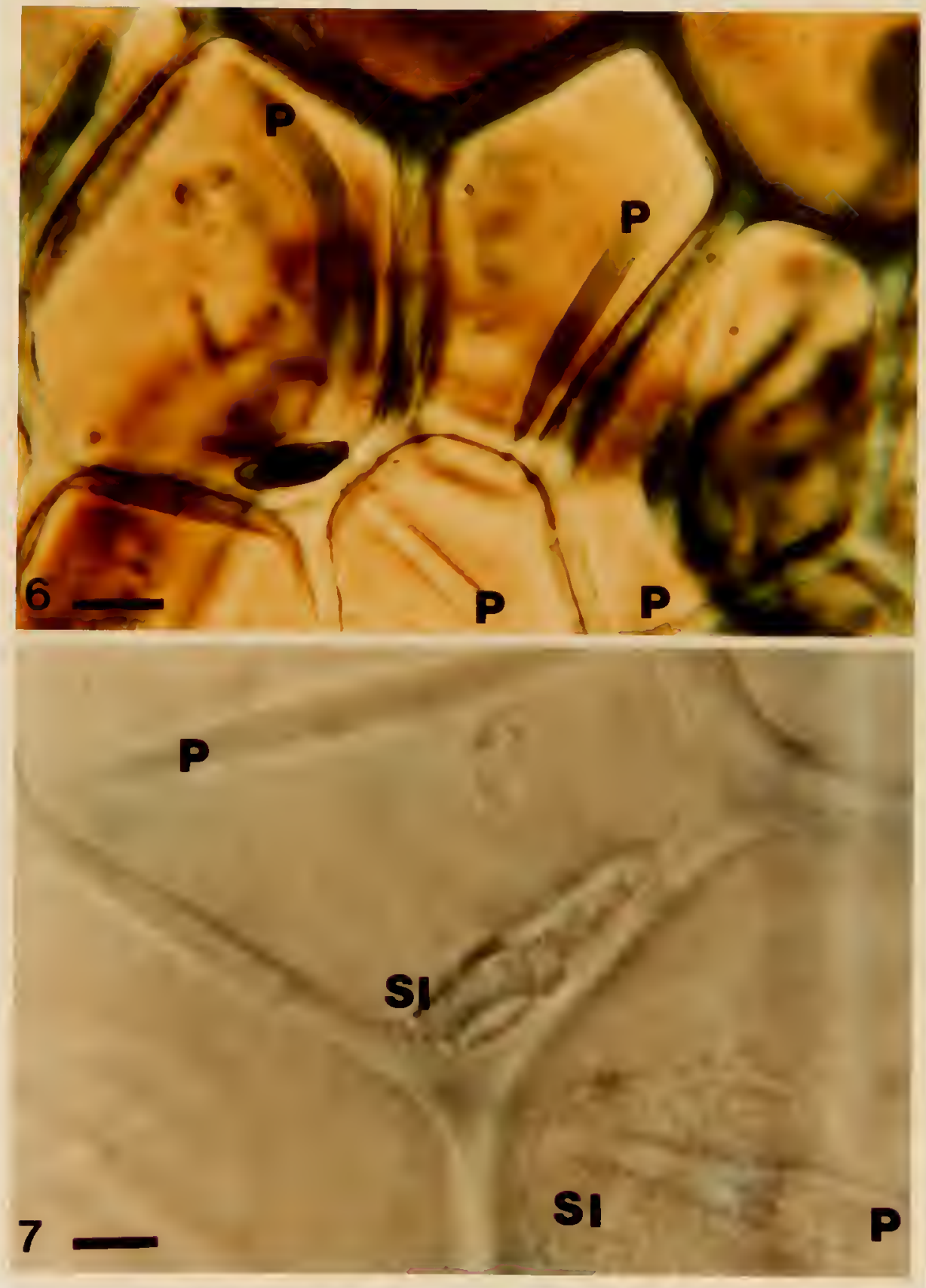

Figure 6. Light micrograph of poorly stained paracrystalline inclusions (P) induced by ORSV in Cattleya leaf cells. Tissue stained with $\mathrm{O} / \mathrm{G}$ without heat. Bar $=3 \mathrm{\mu m}$.

Figure 7. Light micrograph of ORSV-infected Cattleya leaf cells stained with Azure A without heat showing poorly stained inclusions. P: Paracrystal, SI: Stacked-plate inclusion. Bar $=5 \mathrm{\mu m}$. 

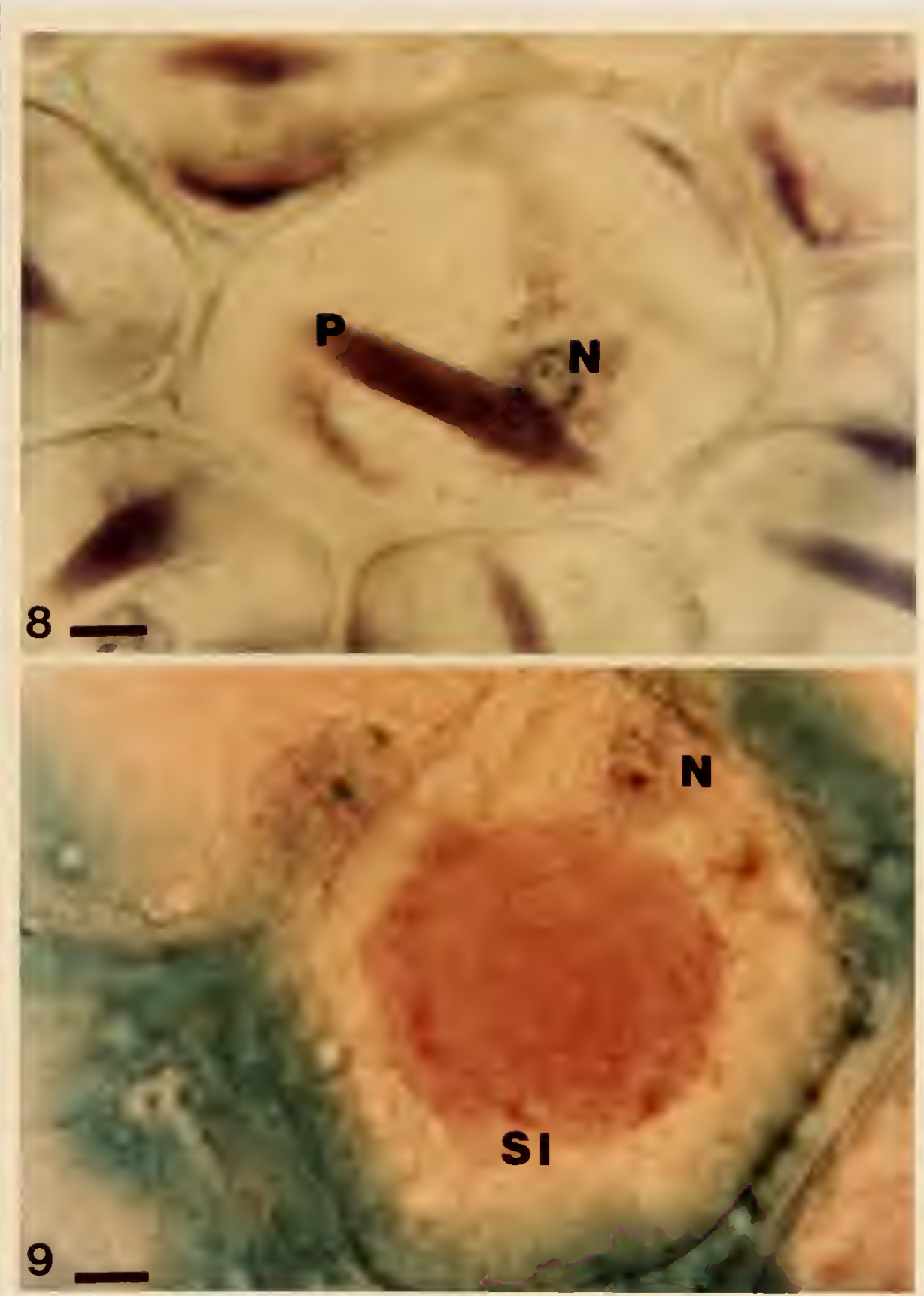

Figure 8. Light micrograph of paracrystal (P) induced by ORSV in Cattleya leaf cells stained with Azure A heated at $60^{\circ} \mathrm{C}$ for $20 \mathrm{~min}$. N: Nucleus. Bar $=3 \mathrm{um}$.

Figure 9. Light micrograph of stacked-plate inclusion (SI) (polar view) induced by ORSV in Cattleya for $20 \mathrm{~min}$. $\mathrm{N}$ : Nucleus. $\mathrm{Bar}=5 \mu \mathrm{m}$. 
tobamoviruses when using Azure A (Christie and Edwardson, $1977)$.

In fluorescence microscopy, the ORSV inclusions fluoresced when treated with TRITC-conjugated ORSV antiserum (refer to chapter 3). However, they did not fluoresce when either TRITCconjugated CyMV antiserum or normal serum was used. Expressed sap from ORSV-infected plants used in this study reacted homologously in SDS immunodiffusion tests with ORSV antiserum. In the bioassay, ORSV infection caused chlorotic spots on the leaves of Gomphrena globosa as described by Lawson and Brannigan (in press). Cymbidium Mosaic Virus

Reddish-violet inclusions typical of other potexviruses were found in Azure A-stained epidermal and mesophyll cells of plants infected with CyMV (Christie and Edwardson, 1977). In glutaraldehyde-fixed tissues, some of these inclusions were banded (Fig. 10). Crescent- or tear-shaped inclusions were also readily found in the Azure A-stained tissues (Fig. 11 ). Thin sections of banded-body inclusions consisted of large aggregates of tiered (Fig. 12) or whorled, and intertwined virus particles (Fig. 13) like those described previously for CyMV and other potexviruses (Chen et al., 1983; Christie and Edwardson, 1977; Hammond and Hul1, 1983; Hanchey et al., 1975; Hiruki et al., 1980; Lawson and Hearon, 1974; Purcifull and Edwardson, 1981).

CyMV-induced inclusions fluoresced when exposed to TRITC-labelled CYMV antiserum (refer to chapter 3), but not 

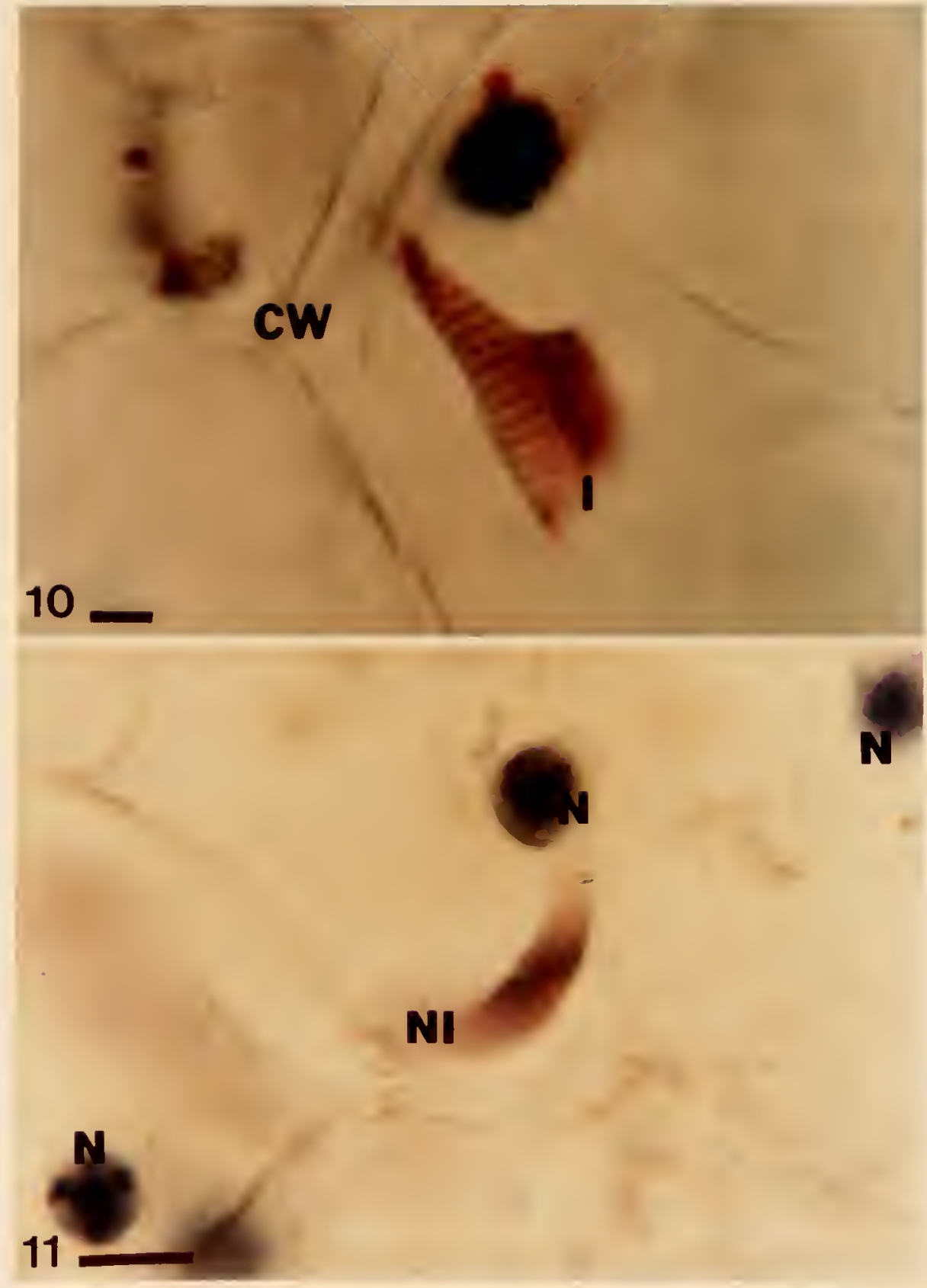

Figure 10. Light micrograph of banded-body inclusion (I) induced by CyMV in cymbidium leaf cell fixed by $5 \%$ glutaraldehyde. CW: Cell wall, N: Nucleus. Bar $=3 \mathrm{\mu m}$.

Figure 11. Light micrograph of non-banded, crescentshaped inclusion (NI) induced by CyMV in Cymbidium leaf cell fixed by 5\% glutaraldehyde. $\mathrm{N}$ : Nucleus. Bar $=2 \mathrm{\mu m}$. 


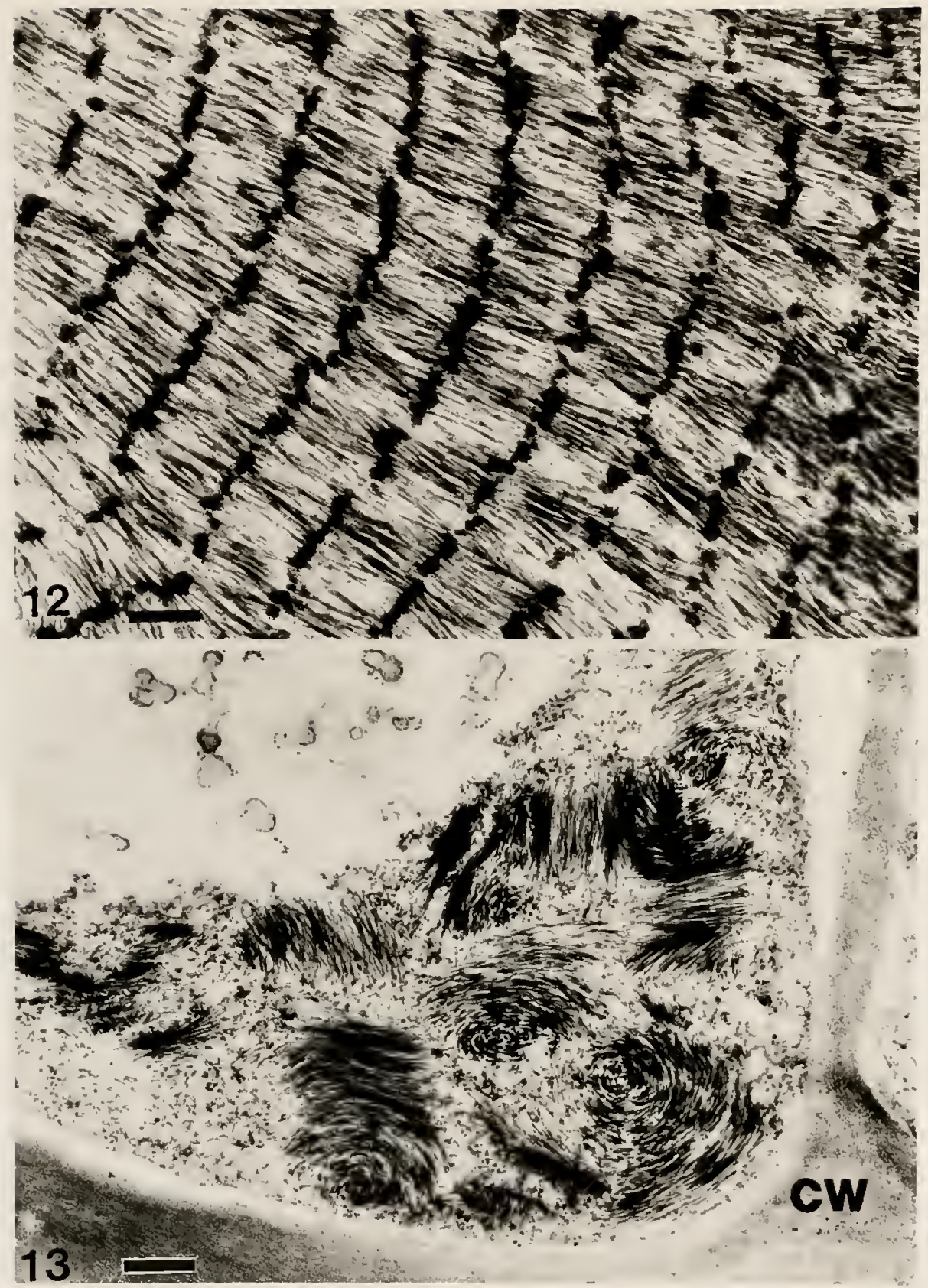

Figure 12. Electron micrograph of a portion of a banded-body inclusion (side view) induced by CyMV in a cymbidium leaf cell. CW: Cell Wall. Bar $=420 \mathrm{~nm}$. Figure 13. Electron micrograph of banded-body inclusions (polar view) induced by CyMV in a Cymbidium leaf cell. CW: Cell Wall. Bar $=360 \mathrm{~nm}$. 
when labelled ORSV or normal serum was used. Reactions of identity were obtained between antigens in expressed sap and antigens of a known CyMV isolate when tested against CyMV antiserum in SDS immunodiffusion tests. In the bioassay, CYMV infection caused dark brown spots on the cotyledons and leaflets of Cassia occidentalis as described by Lawson and Brannigan (in press).

Cucumber Mosaic Virus

Color breaks on the flowers (Fig. 14) and chlorosis on the leaves were found in the Phalaenopsis orchid infected with CMV (Fig. 15). Angular shaped, densely stained inclusions of variable sizes (Fig. 16) were seen in the tissues of this plant. In some instances, the inclusions had clear internal areas, similar to those noted by others for CMV and other cucumoviruses (Christie and Edwardson, 1977). The same type of inclusion was also found in the other systematically infected hosts, such as N. $x$ edwardsonii (Fig. 17). Inclusions were much more abundant in mesophyll than epidermal cells of the orchid flower or leaf tissue. They also occurred much more abundantly in the newly emerged immature leaves. Thin sections revealed these inclusions to consist of massive crystalline arrays of densely packed virus particles (Fig. 18) (Christie and Edwardson, 1977; Russo and Martelli, 1973). Such inclusions fluoresced when exposed to TRITC-labelled CMV antiserum (refer to chapter 3). Expressed sap of CMV-infected tissues reacted homologously in immunodiffusion tests with CMV antiserum produced by kuwite 

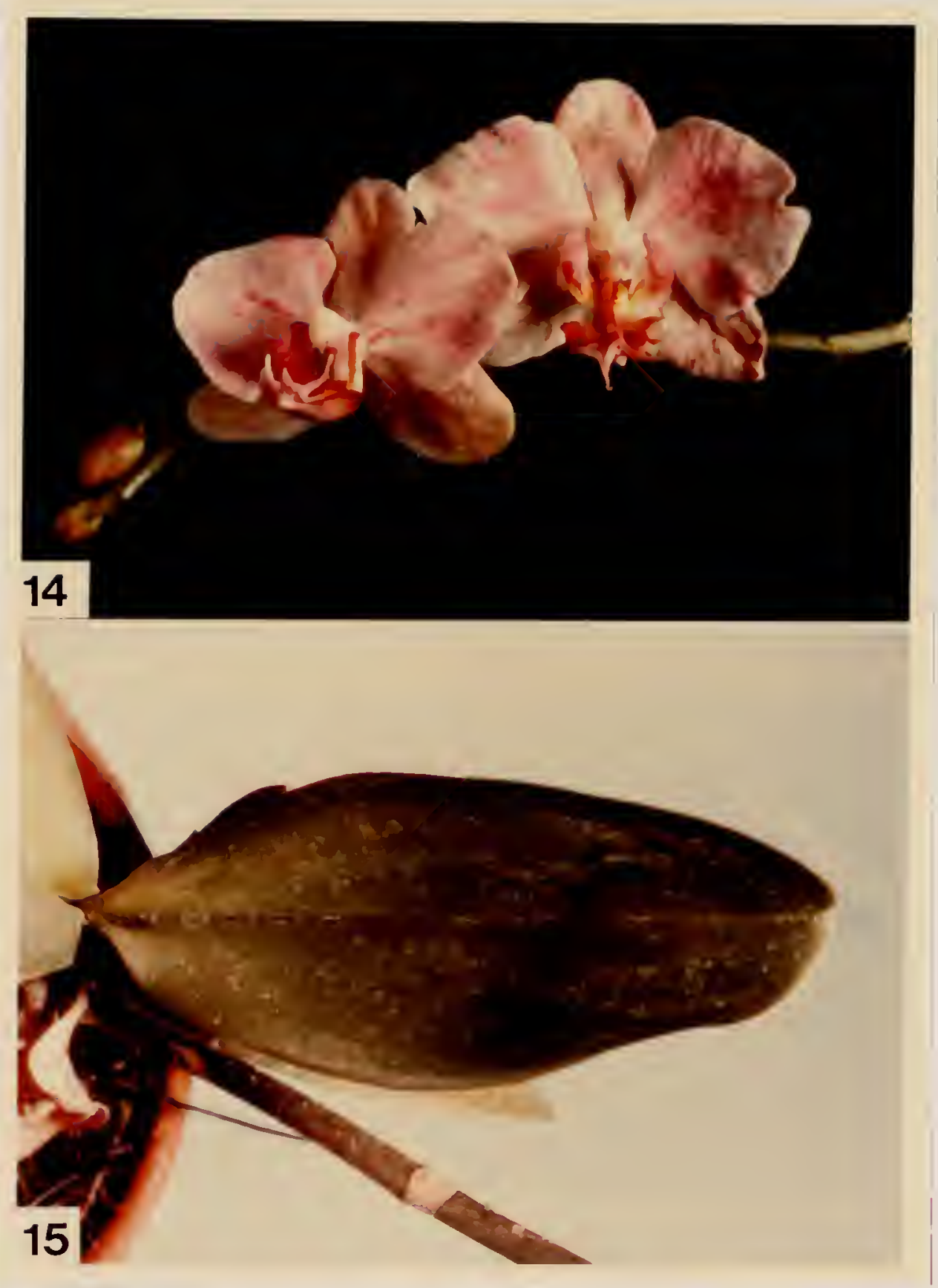

Figure 14. Color breaking of Phalaenopsis flowers caused by CMV infection.

Figure 15. Chlorotic Phalaenopsis leaf infected with CMV. 


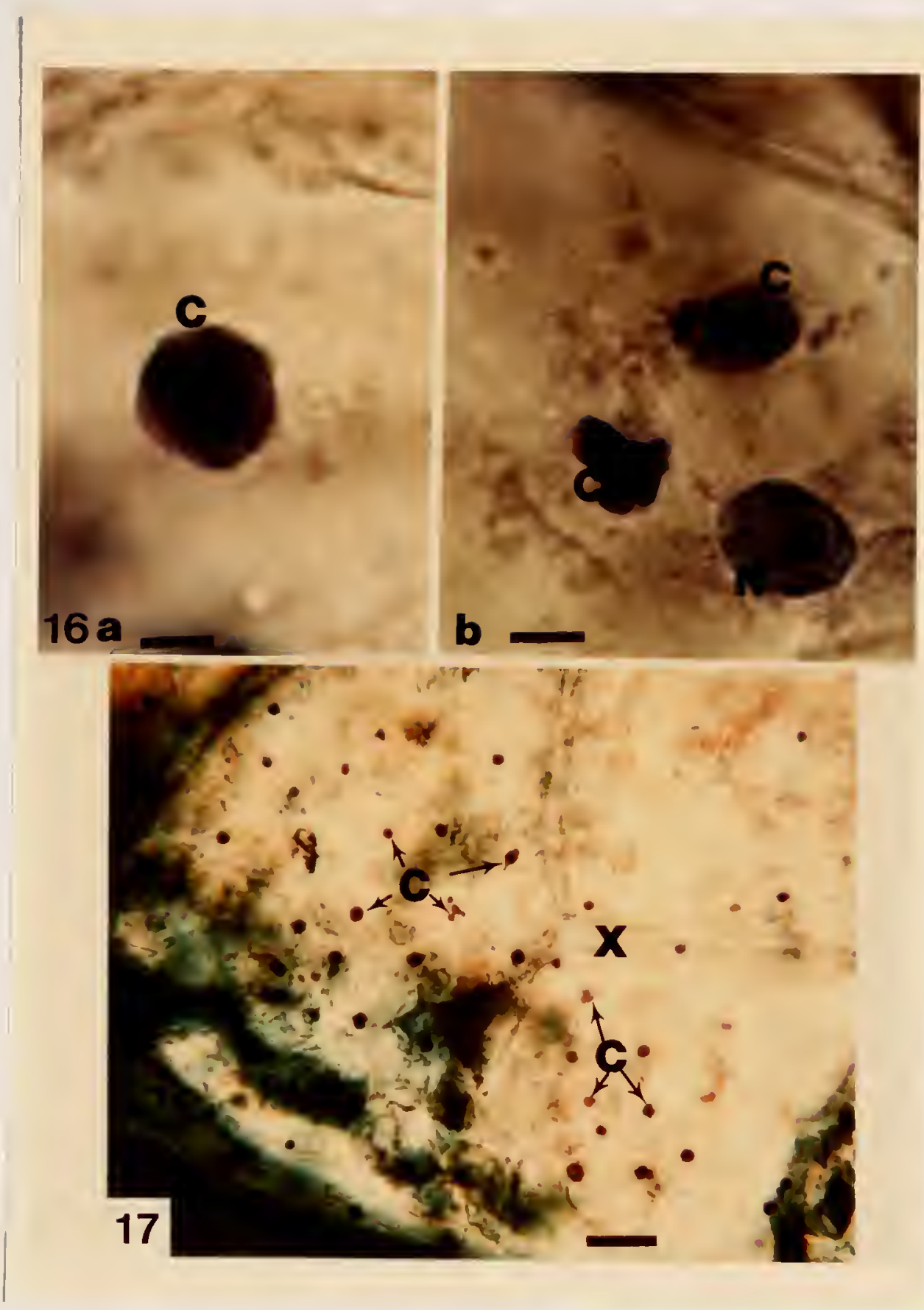

Figure 16. a) and b) Light micrograph of CMV induced crystalline inclusions (C) in Phalaenopsis leaf cells stained with Azure A. N: Nucleus. Bar $=5$ m.

Figure 17. Light micrograph of CMV induced crystalline inclusions (C) in N. $x$ edwardsonii leaf cells stained with Azure $\bar{A}$ in low magnification. $\mathrm{x}$ : Xylem tissue. Bar $=24 \mathrm{~mm}$. 


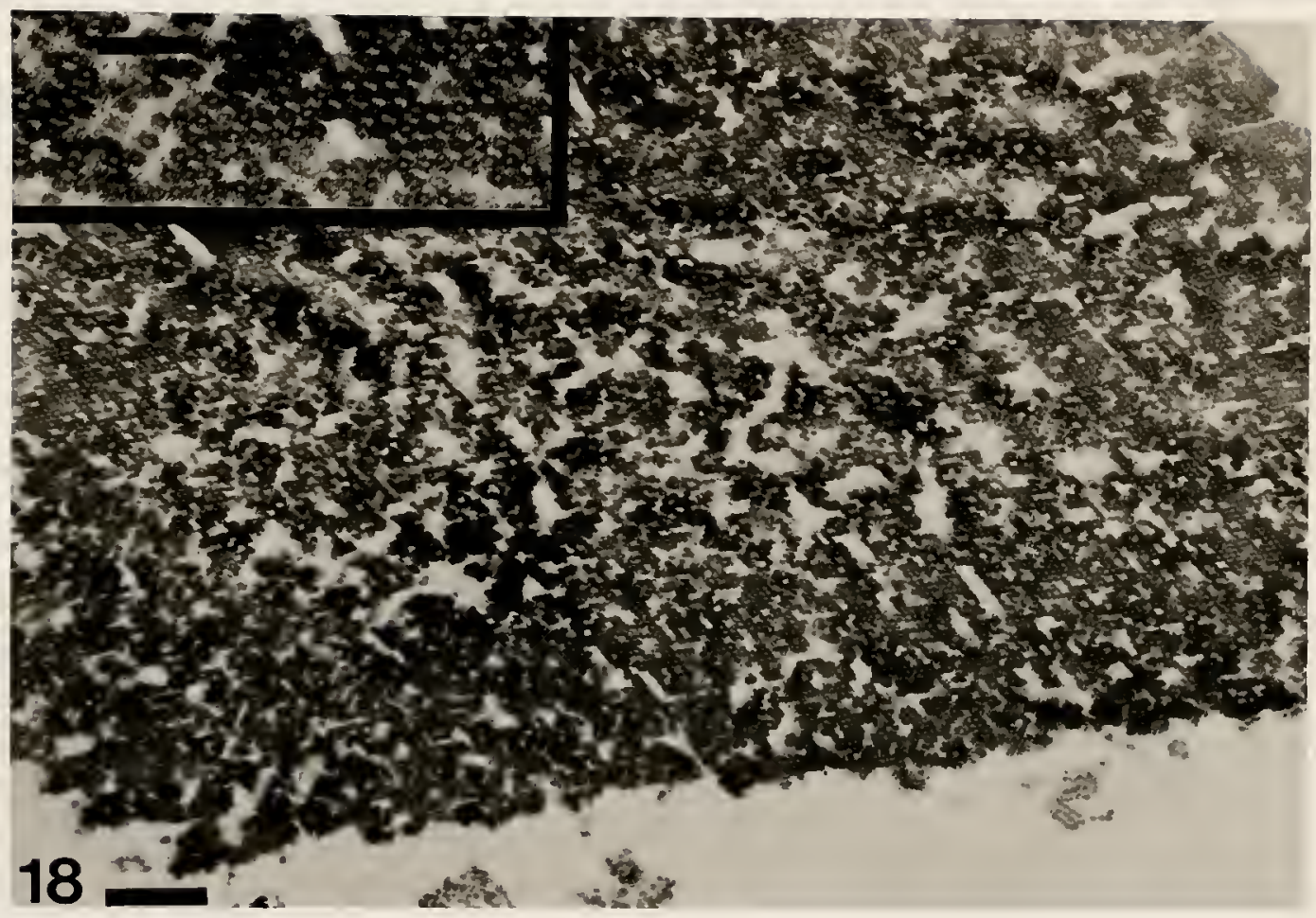

Figure 18. Electron micrograph of a portion of a CMV induced crystalline inclusion in Phalaenopsis petal cell. Bar $=350 \mathrm{~nm}$. Inset shows higher magnification of virus particles. Bar $=120 \mathrm{~nm}$. 
and Purcifuli (1982). It also reacted specifically with CMV antiserum in the undecorated immunosorbent electron microscopy test. This virus was mechanically transmitted to cucumber, tomato, N. benthamiana, N. x edwardsonii, N. glutinosa, N. tabacum Xanthi nc., cowpea, and $\underline{V}$ radiata. It caused systemic infection in the first six hosts and brown-colored lesions in the inoculated leaves of the last two hosts.

Bean Yellow Mosaic Virus

Cytoplasmic inclusions (Fig. 19), typical of potyviruses and stable in 5 \% Triton $x-100$, were not frequently found in epidermal and mesophyll tissues of Masdevallia stained in $0 / G$. These inclusions, which are proteinaceous and do not contain nucleic acid, failed to stain with Azure $A$, as would be expected (Christie and Edwardson, 1977). Thin sections revealed subdivision II cylindrical inclusions (Fig. 21) as described previously for this virus (Edwardson, 1974). Dense bodies such as those described for bean yellow mosaic virus (Zettler and Abo El-Nil, 1977) were rarely found in these sections. Cytoplasmic inclusions were readily detected in the epidermal strips of $\mathrm{N}$. benthamiana, 'Alaska' and 'Ranger' peas (Fig. 20). In thin sections of these tissues, numerous dense bodies and cylindrical inclusions (Fig. 22), which are characteristic ofbean yellow mosaic virus (Edwardson, 1974), were seen. 'Little Marvel' pea plants did not become infected. This is consistent with the reported insusceptibility of this cultivar to BYMV (Zettler and Abo El-Nil, 1977). 


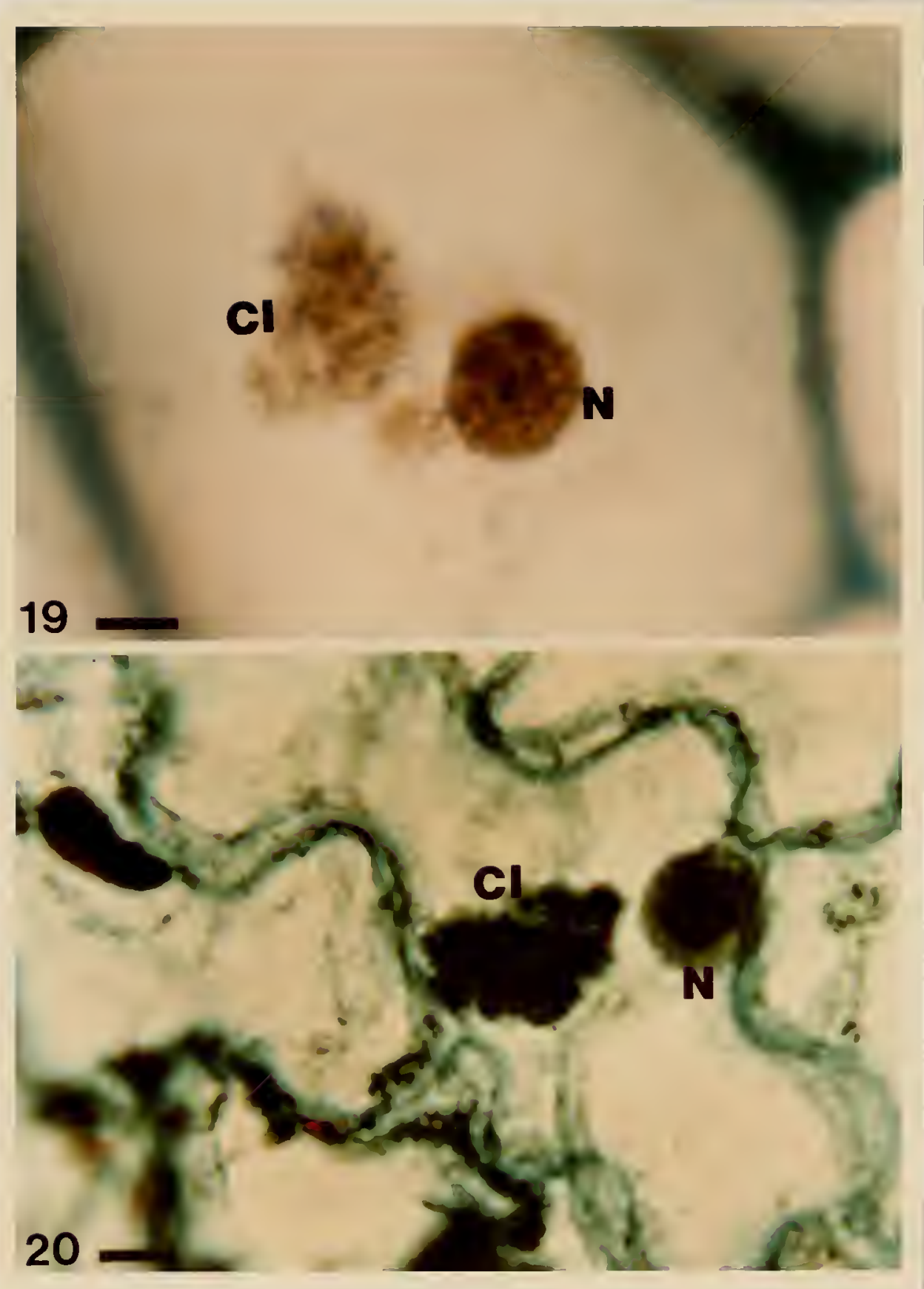

Figure 19. Light micrograph of large group of cylindrical inclusions (CI) induced by BYMV in cytoplasm of a Masdevallia leaf cell stained with $\mathrm{O} / \mathrm{G} . \mathrm{N}$ : Nucleus. $\mathrm{Bar}=5 \mathrm{\mu m}$. Figure 20. Light micrograph of large group of cylindrical inclusions (CI) induced by BYMV in a pea leaf cell stained with $\mathrm{O} / \mathrm{G}$. N : Nucleus. Bar $=5 \mathrm{\mu m}$. 


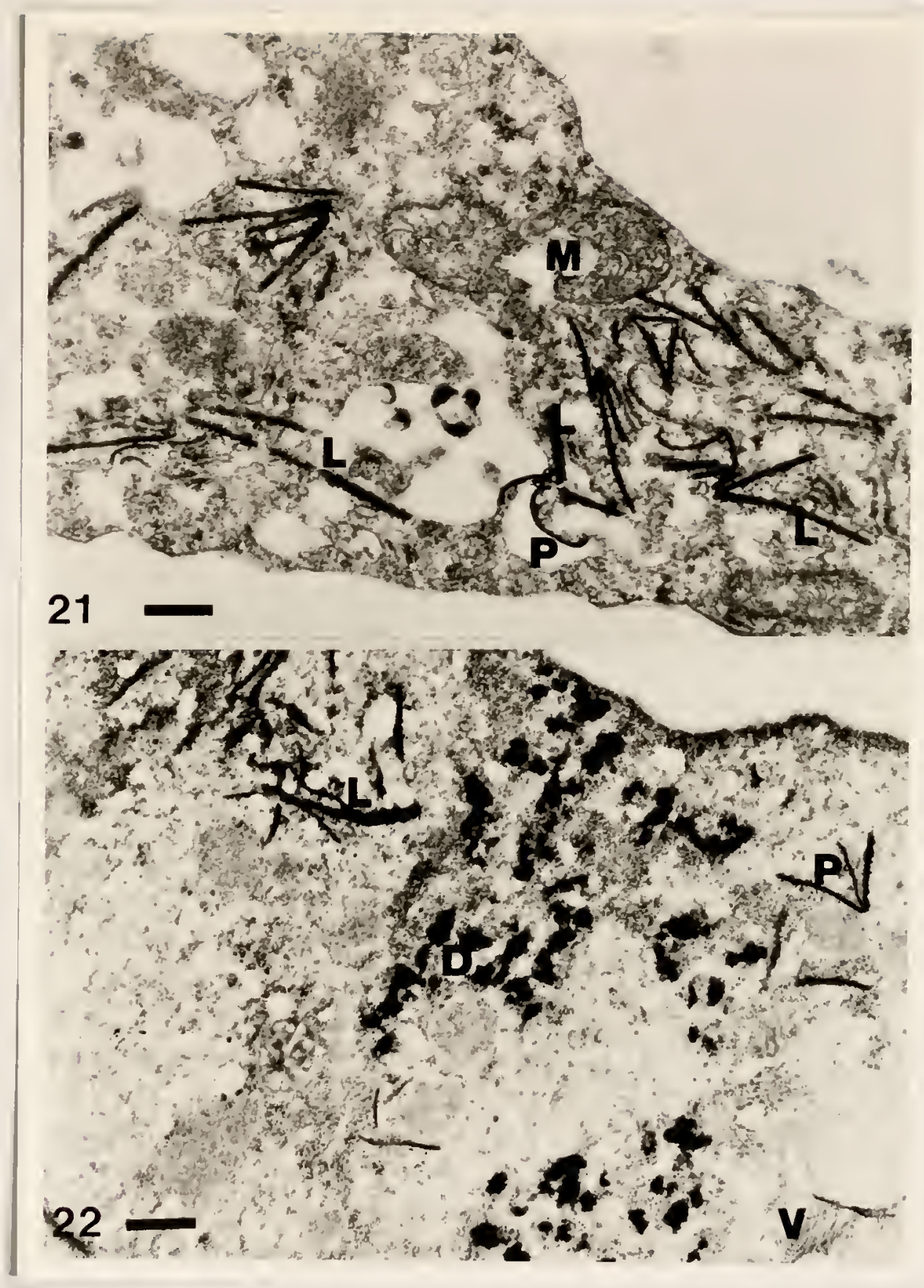

Figure 21. Electron micrograph of BYMV-infected Masdevallia leaf cell showing portions of subdivision II cylindrical inclusions. L: Laminated aggregates, P: Pinwheel arms, M: Mitochondrion. Bar $=340 \mathrm{~nm}$.

Figure 22. Electron micrograph of BYMV-infected pea leaf cell showing subdivision II cylindrical inclusions and dense bodies (D). L: Laminated aggregates, P: Pinwheel arms, V: Virus particles. $\mathrm{Bar}=710 \mathrm{~nm}$. 


\section{Uncharacterized Bacilliform Viruses}

These viruses caused striking symptoms in their hosts. Chlorotic and necrotic fleck lesions occurred on Cymbidium leaves (Fig. 23), while necrotic and ringspot lesions occurred on Brassia leaves (Fig. 24). Nuclear, but not cytoplasmic inclusions were observed in mesophyl 1 and phloem tissues of plants infected with bacilliform viruses. Those in Brassia were relatively large and solitary (Fig. 25b), whereas those found in the Cymbidium specimens were smaller, and usually there was more than one inclusion within each nucleus (Fig. 26). The $O / G$ stain combination readily stained these inclusions (Fig. 27). With Azure A, however, penetration was facilitated considerably by pretreatment of tissues in $1 \%$ Triton $\mathrm{X}-100$ for 10 minutes and heating at $60^{\circ} \mathrm{C}$ for 10 minutes during staining. Without these treatments, the nuclear inclusions did not stain well (Fig. 25a). Thin sections for both isolates revealed rhabdovirus particles. These nuclear inclusions are composed of virus particles and granular materials (Fig. 28). Particles ca. $45 \mathrm{~nm}$ in diameter occurred in aggregates within the nucleus and in the cytoplasm. Those in the cytoplasm were sometimes arranged in a "spokewheel-like" fashion, like those described previously for Dendrobium leaf spot, orchid fleck, and phalaenopsis chlorotic spot viruses (Lesemann and Begtrup, 1971; Petzold, 1971; Lesemann and 


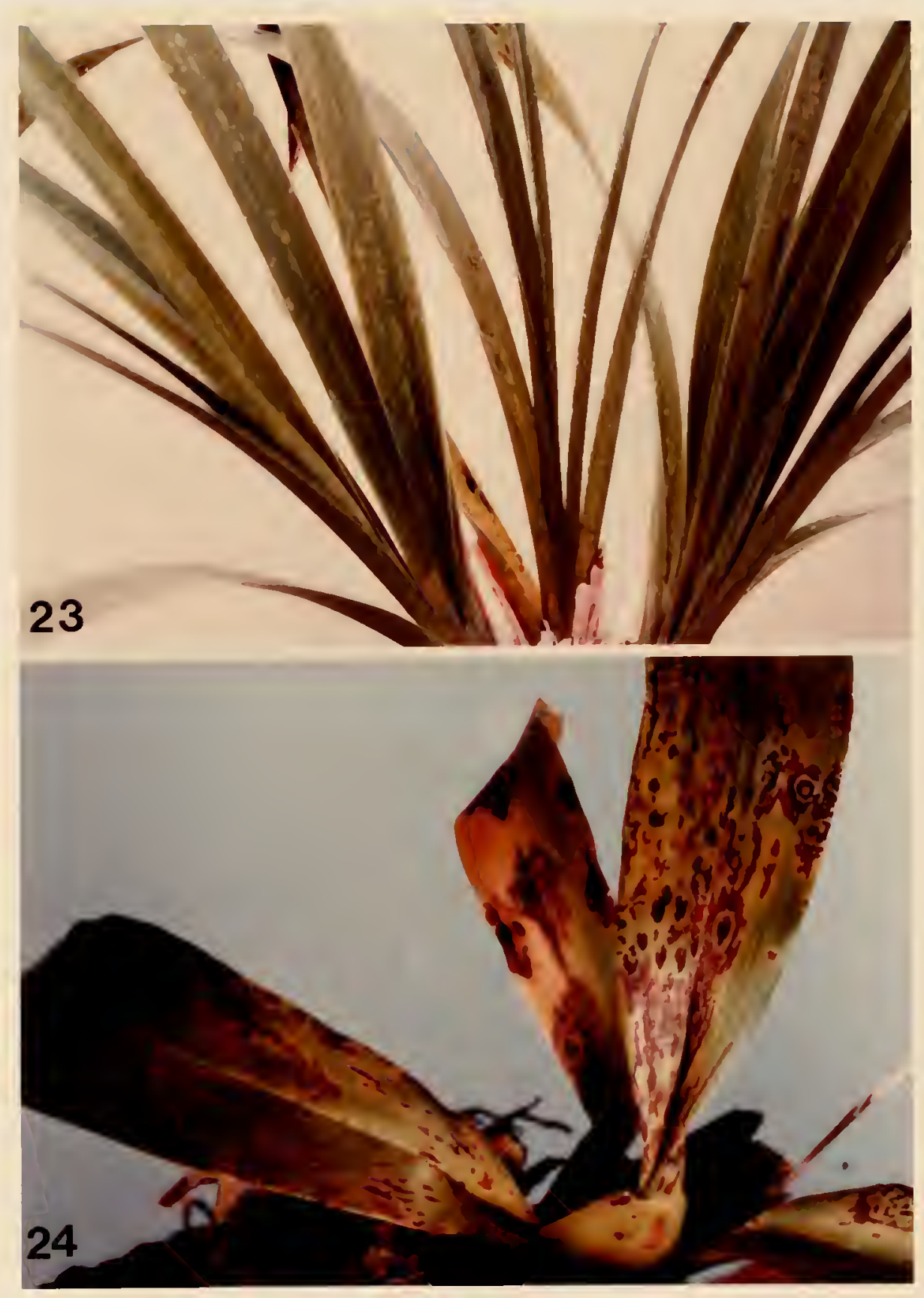

Figure 23. Chlorotic fleck and necrotic lesions of Cymbidium leaves associated with a rhabdovirus infection.

Figure 24. Necrotic and ringspot symptoms of Brassia leaves associated with a rhabdovirus infection. 


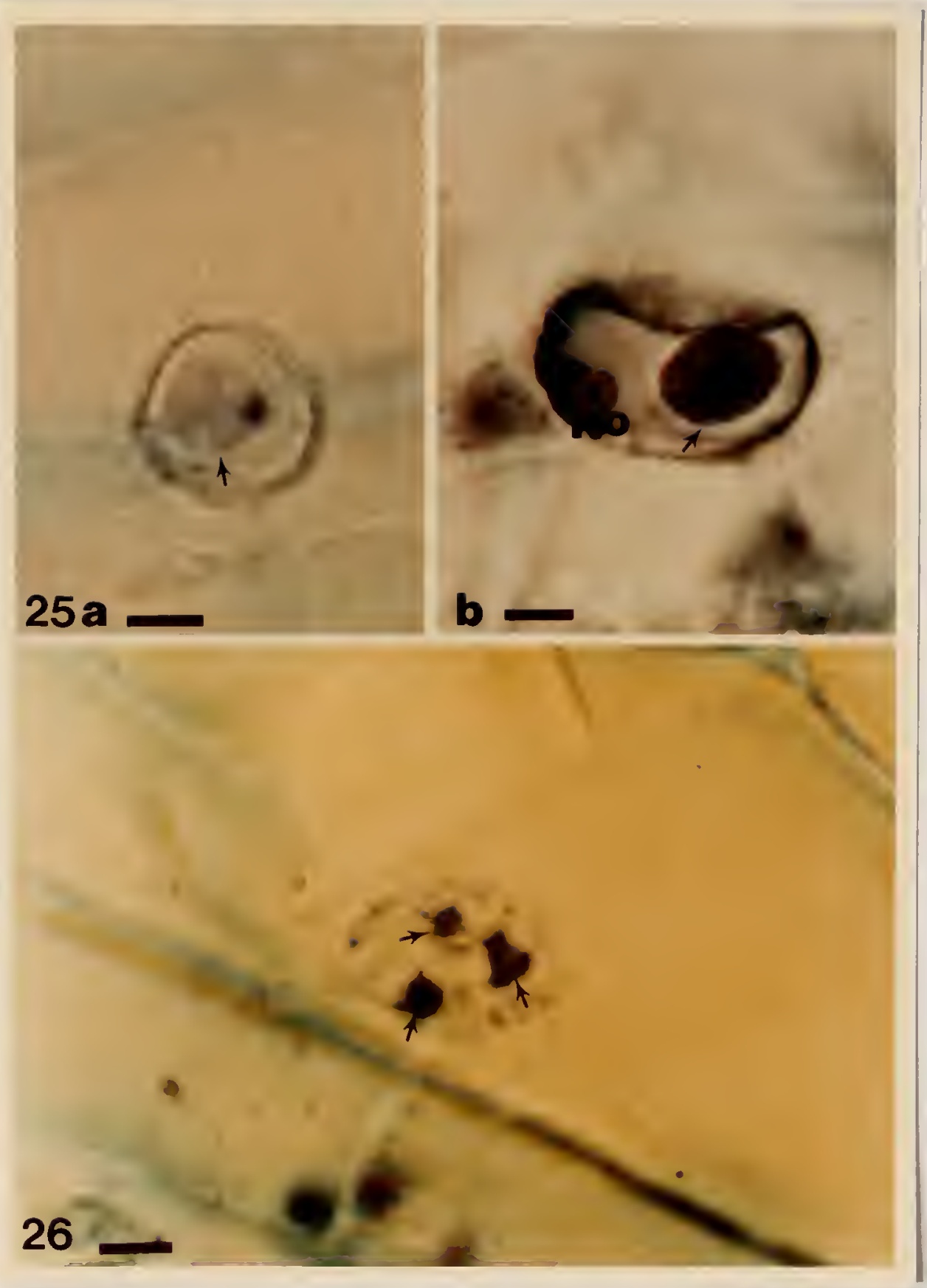

Figure 25. Light micrograph of nuclear inclusions (arrows) induced by a rhabdovirus in Brassia cell stained with Azure A. (a) poorly stained by conventional method. (b) Inclusion well stained after treatment with Triton $\mathrm{X}-100$ and heating to $60^{\circ} \mathrm{C}$ while staining. No: Nucleolus. Bar $=5 \mathrm{~mm}$. Figure 26. Light micrograph of nuclear inclusions (arrows) induced by a rhabdovirus in a Cymbidium leaf cell stained with Azure A. Bar $=5 \mathrm{\mu m}$. 


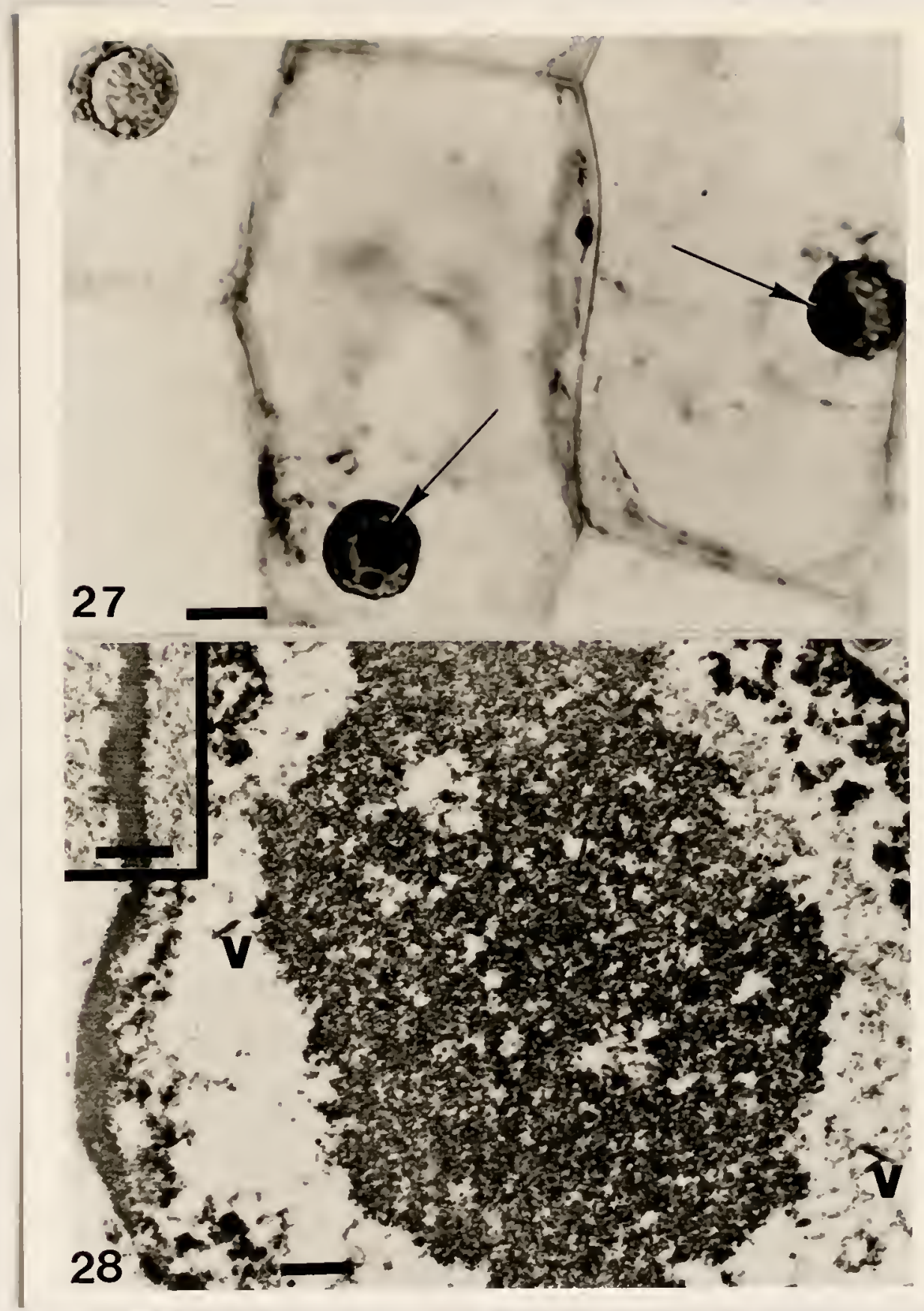

Figure 27. Light micrograph of nuclear inclusions (arrows) induced by a rhabdovirus in Brassia leaf cells stained with O/G. Bar $=10 \mu \mathrm{m}$.

Figure 28. Electron micrograph of a portion of a nuclear inclusion consisting of virus particles and granular materials in a rhabdovirus-infected Brassia leaf cell. V: Virus particles. Bar $=460 \mathrm{~nm}$. Inset showing virus aggregations. Bar $=460 \mathrm{~nm}$. 
Doraiswamy, 1975; Chang et al., 1976). Dispersed virus particles and spokewheel-like virus aggregations were not detected by light microscopy.

\section{Discussion}

Infected orchid tissues examined by light microscopy contained inclusions characteristic of tobamo-, potex-, cucumo-, rhabdo-, and potyviruses (Table I). The diagnoses based on inclusions were confirmed by electron microscopy and, for ORSV, CYMV, and CMV, by fluorescence microscopy using TRITCconjugated antisera and immunodiffusion tests. Thus, like other plant viruses (Christie and Edwardson, 1977), orchid viruses can be reliably detected by light microscopy. While other techniques (i.e., serology, bioassay, electron microscopy) have been used previously for diagnosing orchid viruses (Lawson and Ali, 1975; Lawson and Horst, 1984; Lawson and Brannigan, in press; Corbett, 1974; Wisler and Zettler, in press), this is the first systematic study using light microscopy for this purpose. Potential difficulties posed by the exceptional thickness of most orchid leaves in processing samples can be readily overcome by using sandpaper to abrade the leaf surface or by sectioning leaves. The sandpaper technique also proved useful for working with geminiviruses of legumes (Ko and Christie, unpublished). In some instances, it was necessary to apply mild heating and/or Triton $x-100$ to assure stain penetration, but neither of these modifications induced 
TABLE I. SUMMARY OF STAINING PROCEDURES AND INCLUSION TYPES OF ORCHID VIRUSES

\begin{tabular}{|c|c|c|c|}
\hline \multirow[t]{2}{*}{ VIRUS } & \multirow{2}{*}{$\begin{array}{l}\text { STAINING } \\
\text { PROCEDURE }\end{array}$} & \multicolumn{2}{|c|}{ TYPE OF INCLUSION } \\
\hline & & CYTOPLASMIC & NUCLEAR \\
\hline ORSV & $O / G$, Azure $A$ & $\begin{array}{l}\text { Paracrystal } \\
\text { Stacked plate }\end{array}$ & \\
\hline CyMV & Azure A & $\begin{array}{l}\text { Banded, crescent- } \\
\text { and tear-shaped } \\
\text { inclusion }\end{array}$ & \\
\hline CMV & Azure A & Crystal & \\
\hline BYMV & $0 / G$ & $\begin{array}{l}\text { Cylindrical } \\
\text { inclusion }\end{array}$ & - \\
\hline Rhabdovirus & $\begin{array}{l}\text { Azure } A, \\
O / G\end{array}$ & & $\begin{array}{l}\text { Nuclear } \\
\text { inclusion }\end{array}$ \\
\hline
\end{tabular}


significant problems in processing tissues. Glutaraldehyde fixation is necessary to preserve the configuration and banding of the inclusions in CyMV-infected tissues.

Viruses infecting orchids other than those included in this study have been described, such as Cymbidium ringspot, a tombusvirus (Hollings and Stone, 1977; Hollings et al., 1977; Matthews, 1982). Distinctive inclusions induced by this virus have been described (Russo and Martelli, 1981; Martelli and Russo, 1981). Light microscopy should also be useful in detecting this virus as well. Dendrobium vein necrosis virus, whose properties are similar to those of closteroviruses, should form fibrous and banded-body inclusions in phloem tissue (Lesemann, 1977; Matthews, 1982). These types of inclusion can be detected by light microscopy (Christie and Edwardson, $1977)$.

The specific identities of the rhabdoviruses infecting Brassia and Cymbidium described herein have not been established. The particle dimensions and spokewheel-like configurations are similar to those described for the third subgroup of plant-infecting rhabdoviruses (Matthews, 1982), but their relationship to one another and to the viruses examined in this study remain to be determined. The cylindrical inclusions of bean yellow mosaic virus noted in this study conform to those belonging to "subdivision II" (Edwardson, 1974). However, BYMV cylindrical inclusions and dense bodies occurred rarely in Masdevallia tissues, indicating that they 
could be undetected in studies confined to thin sections. This may be attributed to relatively low virus titers in the orchid host.

The use of light microscopy has special advantages for diagnosing orchid viruses. Many orchid viruses, such as the rhabdoviruses, are poorly characterized, and using alternative techniques for their diagnosis is currently either impractical or unreliable. Light microscopy can be used to detect multiple infections. For example, a Phalaenopsis, which was received for diagnosis, was determined to be triply infected with ORSV, CMV, and a potyvirus. The presence of one virus does not interfere with other viruses with regard to types of inclusions induced. These observations have also been noted for multiple infections of other crops (Edwardson and Christie, 1979; Russo and Martelli, 1973).

Light microscopy proved to be a reliable method for diagnosis of orchid viruses when compared with electron microscopy of negatively stained exudates (Lawson and Brannigan, in press) and immunodiffusion techniques (Wisler et al., 1982). Fifteen of 30 samples (Appendix III) gave the same results with all three techniques. Nine of these were infected with CYMV, ORSV or both viruses; the other six were negative. Infections of either a rhabdovirus or a potyvirus were detected by light microscopy alone in 11 of these samples. In 2 samples, ORSV was detected by serology, but not light microscopy. Additional tests indicated this discrepancy was probably due to a sampling error. 
CHAPTER 3

CONFIRMATORY STUDIES OF

LIGHT MICROSCOPIC OBSERVATIONS

\section{Introduction}

Light microscopy has proved to be very useful in I) viral diagnosis and classification, 2) the selection of tissues for ultrastructural studies, 3) monitoring host tissues for virus infections, and 4) monitoring viral inclusion purification (Christie and Edwardson, 1977; Hiebert et al., 1984). The large field of view, the chemically selective stains, and the speed and ease of tissue preparation and examination are some of the advantages of light microscopy over electron microscopy in studying viruses. In the second chapter, the use of light microscopy for the diagnosis of orchid viruses has been described. However, the resolution of light microscopy is limited. In recent years, the demands for comparative light and electron microscopic studies of individual cells or specific tissue structures has led to the development of various procedures which permit examination of the same tissue area by both types of instrument (Rossi et al.. 1972; Nilsen et al., 1982; Perrie and Webb, 1982). In this study, modified electron microscopic methods are used to reveal the fine structure of viral inclusions whose 
detection by light microscopy were described in the first chapter. In addition, immunofluorescence microscopy and immunogold labelling were used in revealing the specific protein composition of viral inclusions.

\section{Materials and Methods}

\section{$\underline{\text { Leaf Dips }}$}

For CyMV and ORSV, vanadyl molybdate-phosphotungstate (VaMo) was used for negative staining (Boothroyd and Israel, 1980). The Vamo staining solution consisted of 1 part vanadyl molybdate (a mixture of 1 part of 1 \% vanadyl sulphate and 4 parts of $1 \%$ ammonium heptamolybdate), 3 parts of $2 \%$ sodium phosphotungstate and 4 parts of $0.025 \%$ bacitracin. One to 3 cuts were made into virus-infected tissue (ca. $3 \times 4 \mathrm{~mm}$ ) in the freshly prepared staining solution. A drop of this suspension consisting of diffusing plant sap and staining solution was transferred to a grid such that the droplet covered about one-third of the grid. After 30 seconds the excess liquid was removed using a piece of filter paper. The grid was then examined with an electron microscope. The droplet edge was located on the grid at low magnification and then enlarged to locate virus particles accumulated there. The phosphotungstic acid (PTA) staining was processed in the same manner as Vamo staining. 


\section{Thin Sectioning}

After staining with either the $\mathrm{O} / \mathrm{G}$ combination or Azure A (see Chapter 2), ORSV-infected tissues containing inclusions were rinsed with $50 \%$ ethanol to remove Euparal and then fixed with $5 \%$ glutaraldehyde and postfixed with 1-2\% osmium tetroxide. Tissues were then dehydrated with acidified 2,2-dimethoxypropane as described by Muller and Jacks (1975), and embedded in Spurr's low-viscosity medium (Spurr, 1969). Sections were made with either a glass or a diamond knife and stained with potassium permanganate, uranyl acetate, and lead citrate (ko and Chen, 1982).

The $O / G$ and Azure $A$ stains were used to select tissues infected with ORSV, CYMV, CMV, BYMV and rhabdoviruses to be processed for embedding. Semithin (0.5-1.0 Mm) sections were cut with a glass knife mounted on a sorvall Porter-Blum MT2-B ultramicrotome. Sections were then placed on a glass microscope slide and stained with $1 \%$ toluidine blue $(\mathrm{w} / \mathrm{v}$ dissolved in $1 \%$ sodium borate solution) for $10-30$ seconds on a hot plate at $55-60^{\circ} \mathrm{C}$. The semithin sections were then examined by light microscopy. When inclusion-containing areas were located, ultrathin sections were made from the same block still mounted on the microtome. Resulting ultrathin sections were stained in a conventional manner as described above and examined with an electron microscope. 
Immunofluorescence Microscopy

Non-fixed ORSV-infected Cattleya, CMV-infected

Phalaenopsis and fixed ( $5 \%$ glutaraldehyde) CyMv-infected Cymbidium tissues were used. The CMV antiserum used was obtained from D. E. Purcifull (Kuwite and Purcifull, 1982) and the antiserum against ORSV and CyMV from G. C. Wisler (Wisler et al., 1982). The immunoglobulins (IgG) of CMV, CYMV and ORSV antisera were purified by the use of protein A-Sepharose CL-4B (Pharmacia Fine Chemicals, Sweden) as described by Miller and stone (1978). IgG was conjugated with TRITC by dialysis (Hiebert et al., 1984). Healthy tissue extracts were made by triturating tissues with 10 volumes $(\mathrm{w} / \mathrm{v})$ of $20 \mathrm{mM}$ sodium phosphate buffered saline at $\mathrm{pH} 7.4$ (PBS). The extracts were then filtered using Whatman No. I filter paper. The staining solution was made by mixing $27 \mathrm{\mu l}$ TRITC-conjugated antiserum, $27 \mathrm{\mu l}$ healthy tissue extract, and 6 ul dimethylsulphoxide (DMSO) in saline (Herbert et al., 1982). This solution was incubated for 30 minutes before tissue staining. Tissue sections prepared as described in Chapter 2 were floated on the above solution for another 30 minutes. After incubation, tissue sections were blotted with filter paper, washed three times with $20 \mathrm{mM}$ PBS and incubated for another 15 minutes on top of a large drop (about 200 al) of PBS. All the procedures were carried out in a moist chamber at room temperature $\left(\mathrm{ca} \cdot 25^{\circ} \mathrm{C}\right)$. Tissue sections were picked up 
with the aid of a wooden applicator stick, blotted with filter paper and transferred to an aqueous, nonfluorescing medium (Aqua-mount, Lerner Laboratories, New Haven, Connecticut 06513) placed upon a glass microscope slide. A cover slip was then placed over the mounting medium and the tissues were observed with a Nikon (Nippon Kogaku K. K., Tokyo, Japan) Fluophot microscope with epiillumination capabilities. The interference excitation filter and barrier filter were used. Observations were recorded with an automatic camera using Kodak Ektachrome 400 film (Eastman Kodak Co., Rochester, New York). TRITCconjugated normal serum and heterologous antisera were used for staining infected tissues as controls. Healthy tissues were also studied as controls.

Protein A-Gold Labelling

A solution of protein A-gold (containing colloidal gold particles $15 \mathrm{~nm}$ in diameter) was passed through a $0.2 \mu \mathrm{m}$ millipore filter before use. The tissues studied were as follows: CMV-infected Phalaenopsis, BYMV-infected pea, ORSV-infected Cattleya, CyMV-infected Cymbidium and healthy Cattleya and Cymbidium. These tissues were fixed with 5\% glutaraldehyde and dehydrated through an ethanol series $(25,50,75,95,100 \%)$, and embedded in LR white resin, medium grade (Polaron Equipment Limited, Hertfordshire, England). Polymerization of LR White resin 
was done at $55-60^{\circ} \mathrm{C}$ for 12 hours. Ultrathin sections were placed upon Formvar carbon-coated copper grids and exposed to $10 \%$ ovalbumin solution for 10 minutes. The excess liquid was then blotted from the grids with filter paper. Following this, grids were floated on a drop of PBSdiluted antiserum (1/500-1/2000) for 30 minutes. Grids were then rinsed 3 times with $20 \mathrm{mM}$ PBS buffer for 10 minutes each and then incubated with protein A-gold for 30 minutes. Finally, grids were rinsed with PBS buffer for 20 minutes, followed by a 10 minute rinsing in distilled water. The sections were poststained with $2 \%$ uranyl acetate and $0.2 \%$ lead citrate and examined by electron microscopy. Tissues incubated with normal serum were used as controls for all samples studied.

\section{$\underline{\text { Results }}$}

\section{VaMo Negative Staining}

The Vamo negative staining method was very useful for detecting CYMV and ORSV particles in orchid leaf and flower tissues. With this method, most virus particles accumulate at the edge of the staining solution on the grid and appear with good contrast and resolution (Figs. 29, 30 and 32 ). With the conventional PTA negative staining method, virus particles were not concentrated at 
the edge of the staining solution (Fig. 31), nor anywhere else on the grid.

\section{Thin Sectioning}

Tissues examined by electron microscopy could be directly compared to and correlated with those seen by light microscopy when either the $O / G$ or toluidine blue methods described in this study were used. ORSV inclusions were readily located by light microscopy after the tissues were stained with the $O / G$ combination and subsequently could be processed for embedding and thin sectioning. After ultrathin sections were made, the same inclusions observed by light microscopy were also seen by electron microscopy. However, the fine structure of the cells and the inclusions at the ultrastructural level was poorly resolved (Fig. 34). When Azure A was used, those fine structures were even more poorly resolved. More satisfactory results were obtained by using the toluidine blue method. Semithin sections $(0.5-1.0 \mu \mathrm{m})$ were made with an ultramicrotome and stained with $1 \%$ toluidine blue. Although this dye stains cell structures in a nonselective manner, the viral inclusions can still be recognized by their characteristic morphology and can thus be differentiated from cell organelles in these semithin 


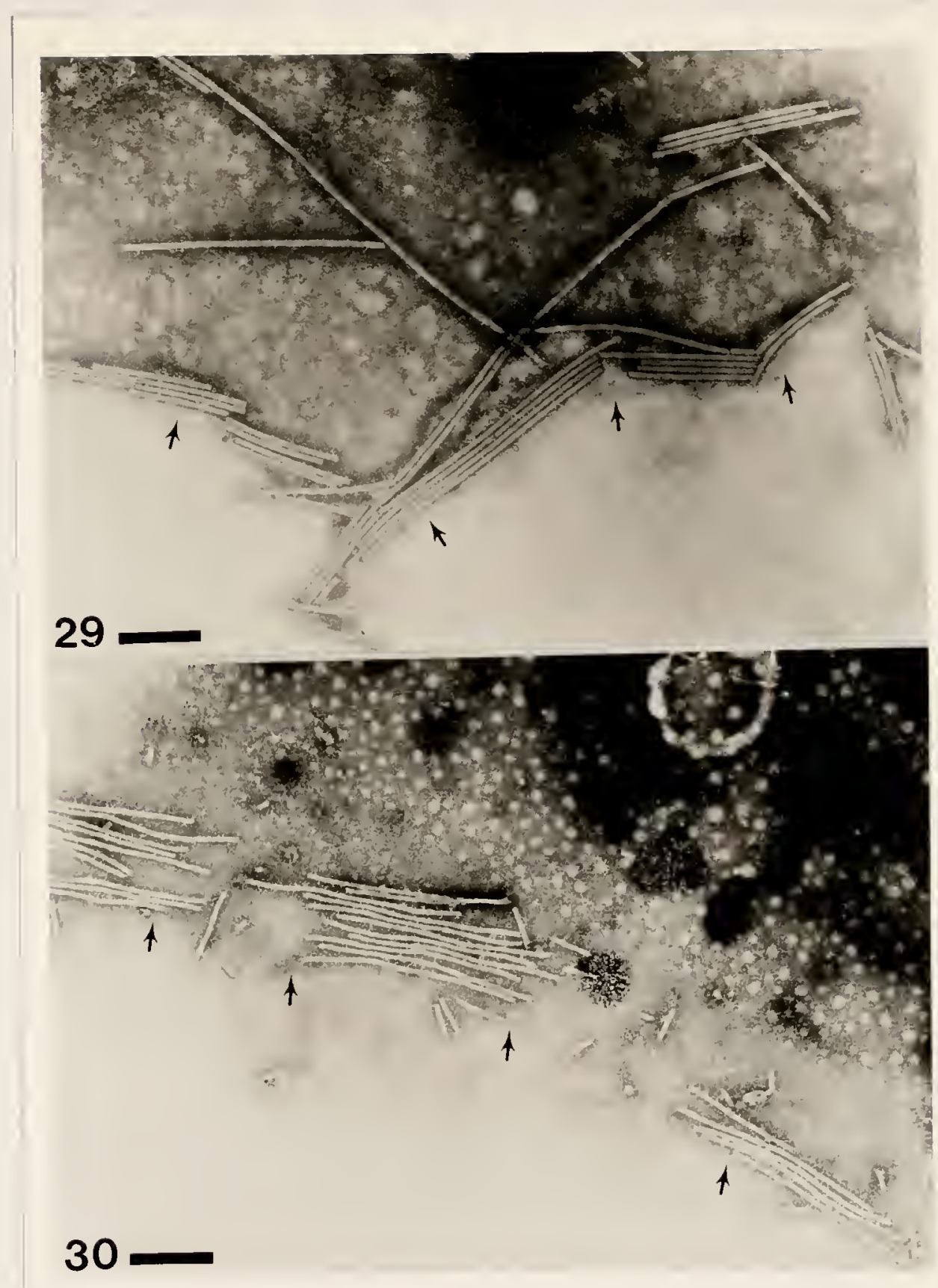

Figure 29. Electron micrograph shows the accumulation of VaMo-stained ORSV particles at droplet edge (arrows) in Cattleya leaf extracts. Bar $=200 \mathrm{~nm}$.

Figure 30. Electron micrograph shows the accumulation of VaMo-stained CyMV particles at droplet edge (arrows) in Cymbidium leaf extracts. $\mathrm{Bar}=200 \mathrm{~nm}$. 


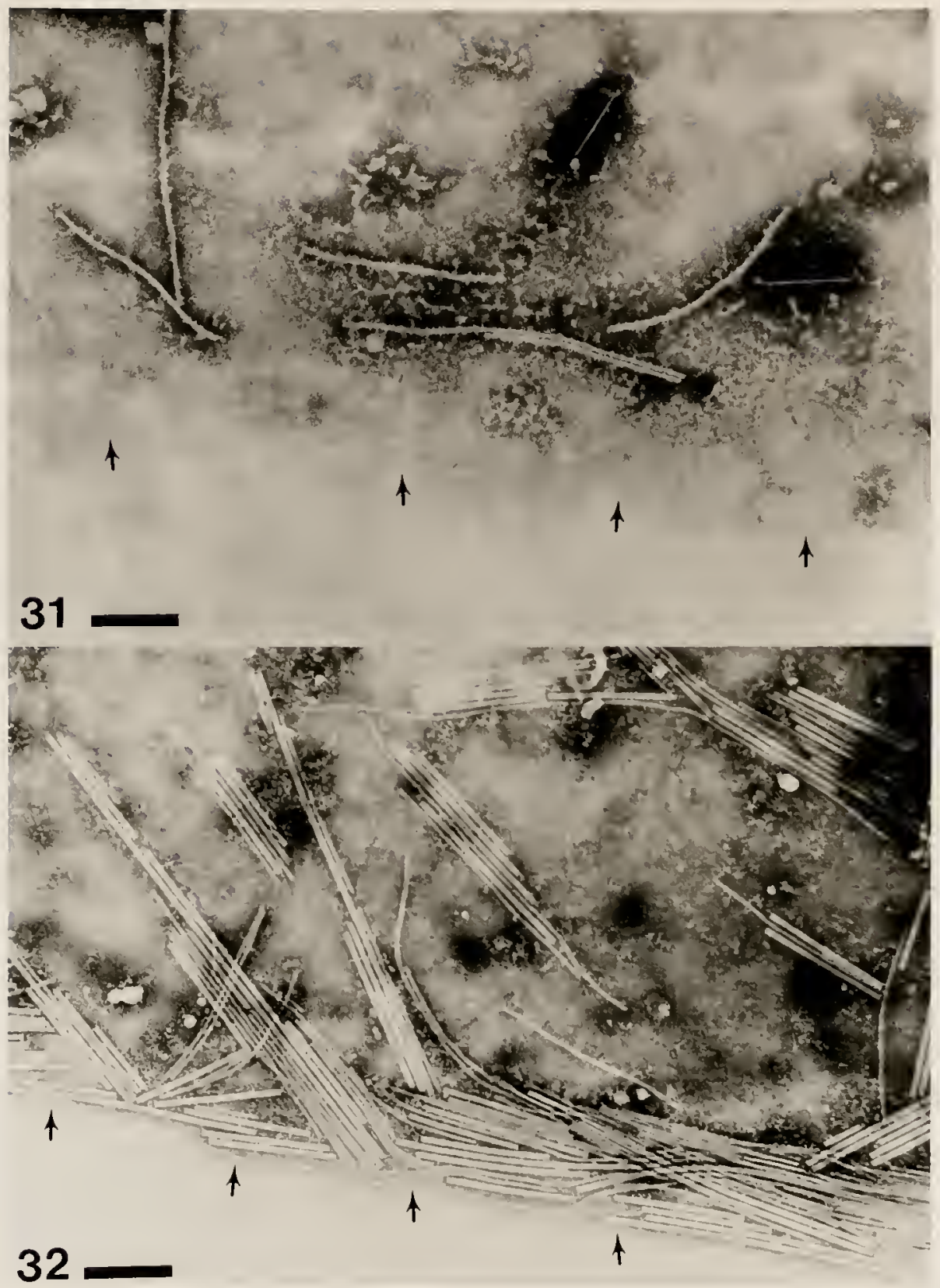

Figure 31. Electron micrograph shows the presence of PTA-stained few CyMV particles at droplet edge (arrows) from the same tissue as in Fig. 30. Bar $=200 \mathrm{~nm}$.

Figure 32. Electron micrograph shows the accumulation of VaMo-stained CyMV and ORSV particles at droplet edge (arrows) in high concentration in an extract from a Cymbidium leaf infected with both viruses. $\mathrm{Bar}=200 \mathrm{~nm}$. 


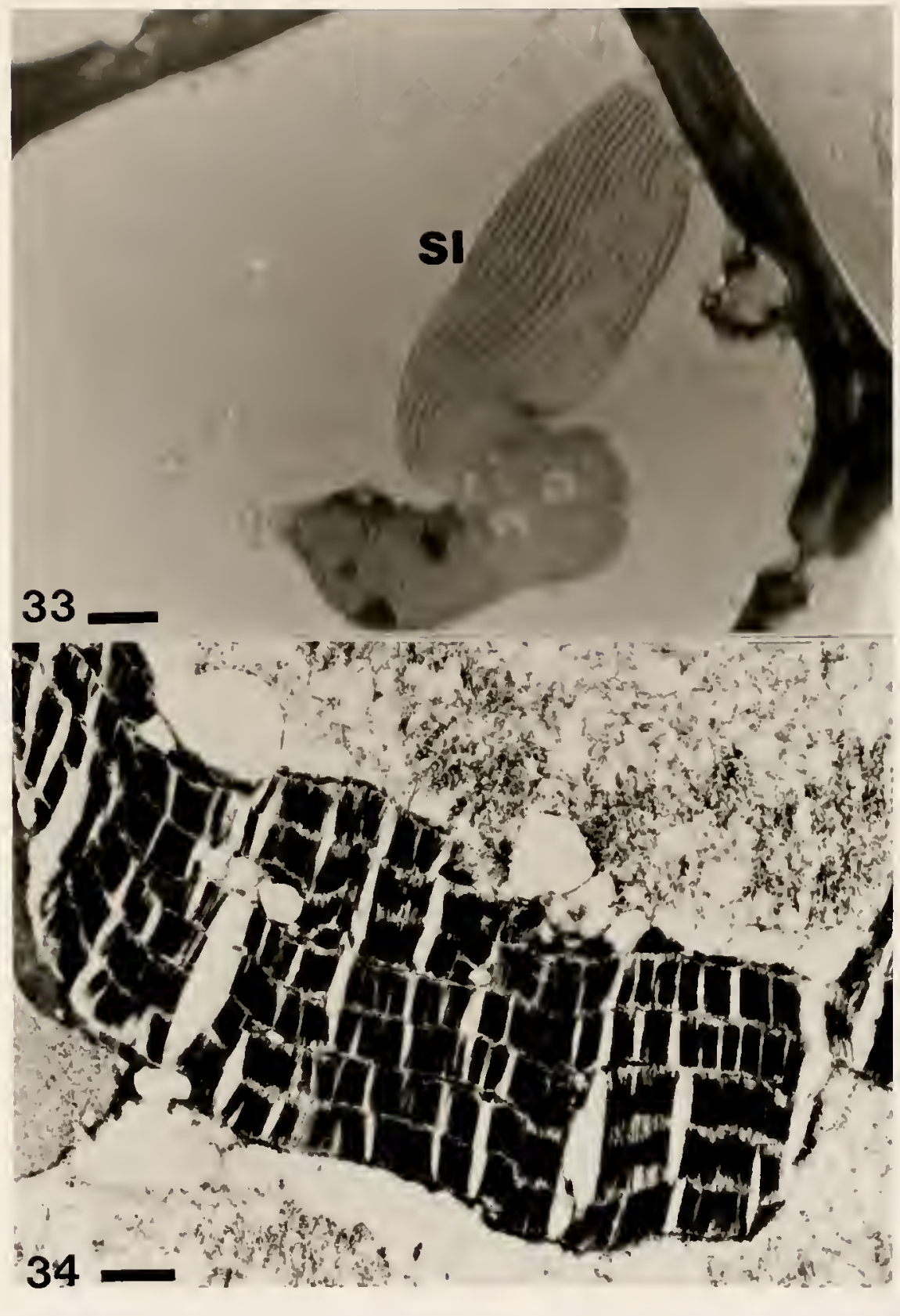

Figure 33. Light micrograph of ORSV-infected cells showing a stacked-plate inclusion (SI, side view) in semithin section $(0.5 \mathrm{rm}$ thick). Section is stained with toluidine blue. Bar $=5 \mathrm{\mu m}$.

Figure 34. Electron micrograph of ORSV stackedplate inclusion (side view) in Cattleya leaf cells stained with $O / G$ combination. Bar $=600 \mathrm{~nm}$. 
sections (Figs. 33, 35, and 38). Sections of these same tissue areas can be obtained for electron microscopy by taking an ultrathin section from the same block from which the toluidine blue section is obtained. The same inclusions can thus be located (Fig. 36 and 39) in these ultrathin sections by their intracellular location in relation to cell organelles noted by light microscopy. Using this method, ORSV, CYMV and CMV inclusions composed of virus particle aggregations (Figs. 34 and 36 ) were located, as were BYMV inclusions, which were comprised of cylindrical inclusions. Nuclear inclusions containing rhabdovirus particles and granular electron dense materials (Fig. 39) were also located by this method. Immunofluorescence Microscopy

As described in the chapter 2, CYMV inclusions were preserved by glutaraldehyde fixation. In this investigation, it appeared that glutaraldehyde fixation did not change the properties of CyMV inclusion antigenicity since they still reacted with virus specific antiserum (Figs. 40 and 41 ). In the newly emerged CMVinfected leaves or flowers of Phalaenopsis, CMV crystal inclusions were easily observed, although the size of crystals varied (Fig. 42). In ORSV-infected Cattleya tissues, the paracrystal and stacked-plate inclusions fluoresced (Figs. 43,44, 45 and 46). These virusinfected tissues did not fluoresce when they were 


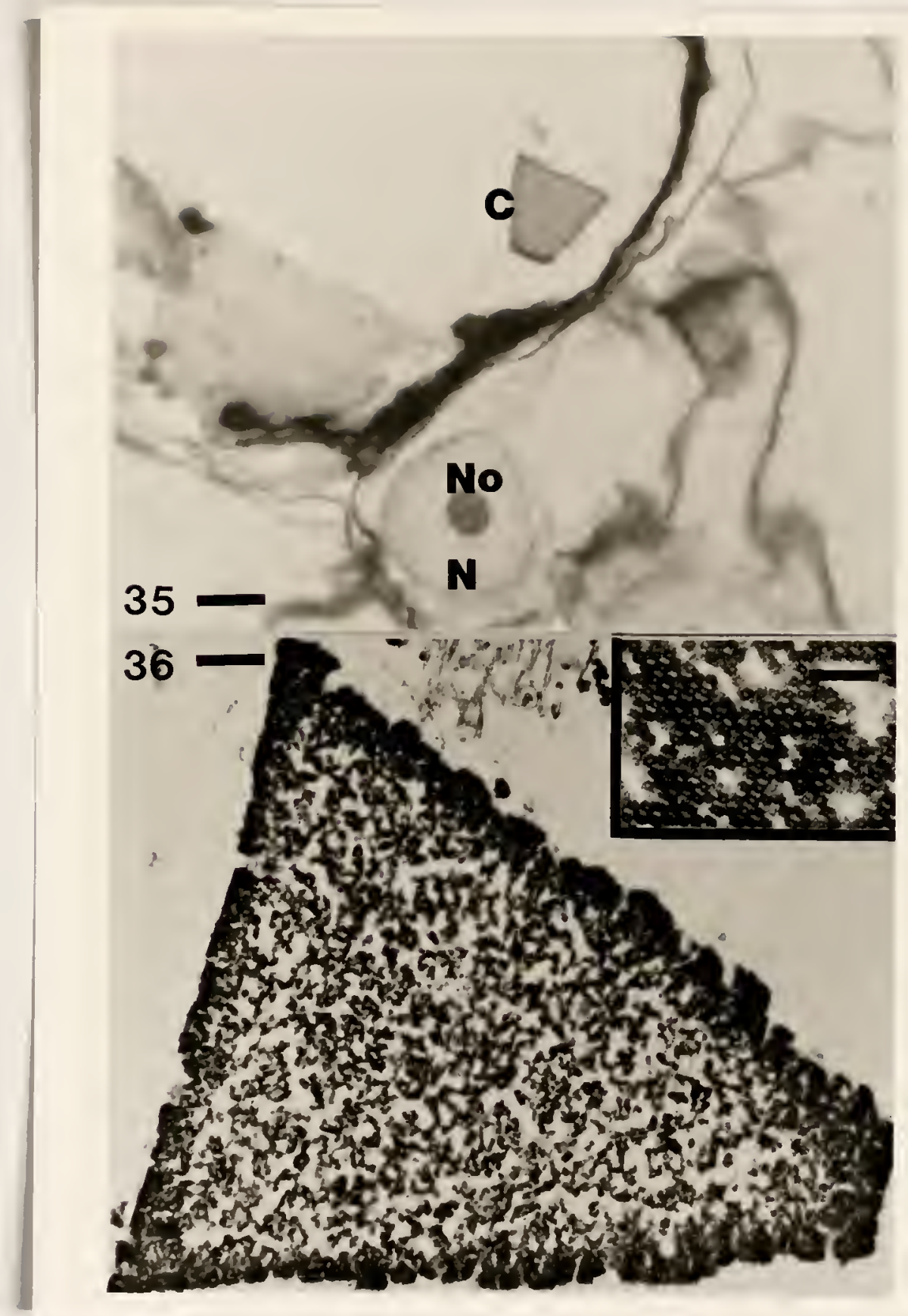

Figure 35. Light micrograph of CMV-infected cell showing the angular crystal (C) stained with toluidine blue in semithin section

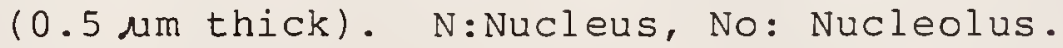
$\mathrm{Bar}=5 \mathrm{\mu m}$.

Figure 36. Electron micrograph of the same CMV crystal shown in Fig. 35. Bar $=545 \mathrm{~nm}$. Inset showing a portion of the same crystal in higher magnification. Bar = $120 \mathrm{~nm}$. 


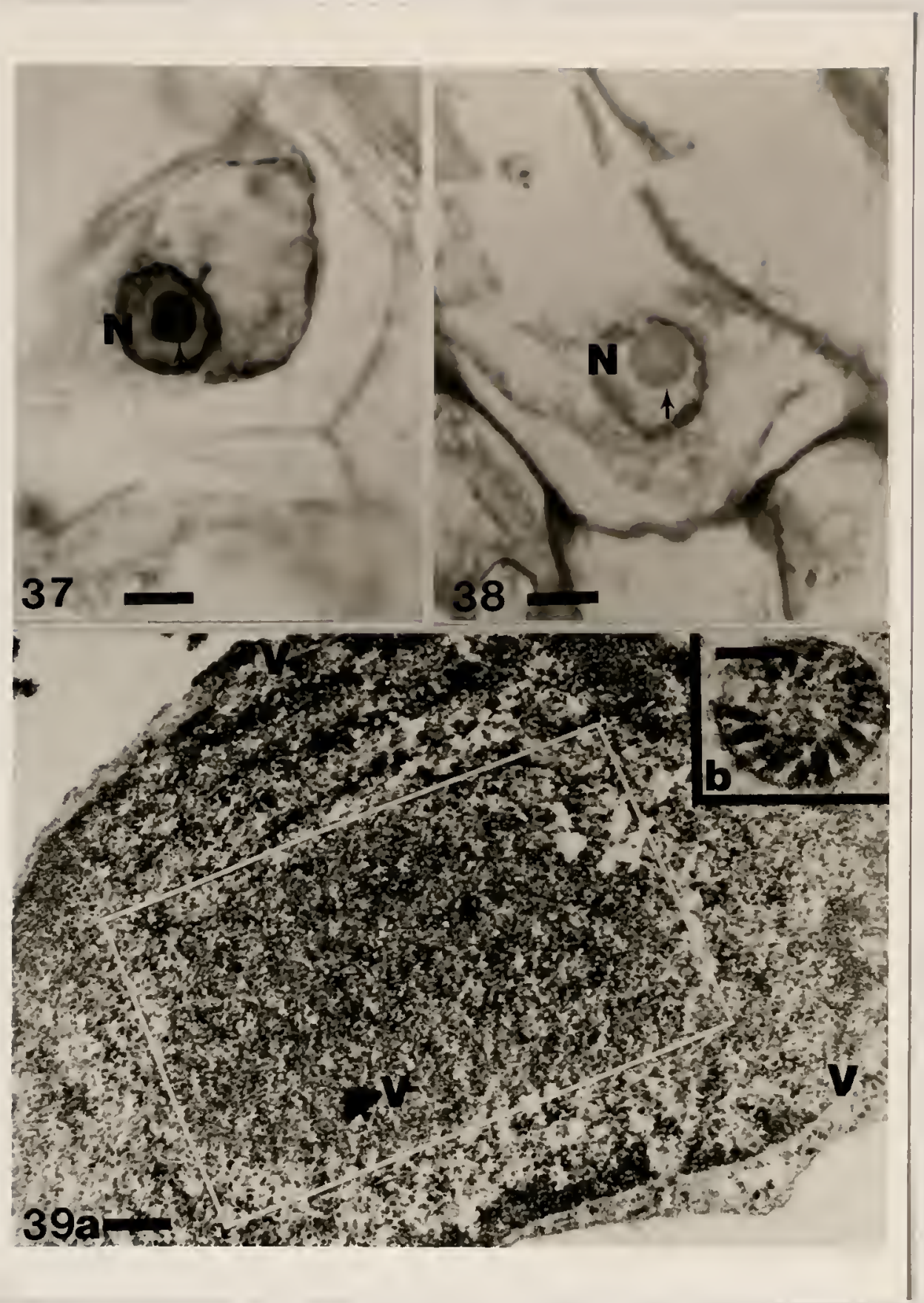

Figure 37. Light micrograph of nuclear inclusion (arrow) induced by a rhabdovirus in Brassia leaf cell stained with $O / G$. N:Nucleus. Bar $=5 \mathrm{\mu m}$.

Figure 38. Light micrograph of nuclear inclusion (arrow) induced by a rhabdovirus in semithin section (0.5 $\mathrm{\mu m}$ thick) of Brassia leaf cell. $\mathrm{N}$ : Nucleus. Bar $=5 \mu \mathrm{m}$.

Figure 39. a) Electron micrograph of nuclear inclusion of Brassia rhabdovirus. V:Virions. Rectangle shows the location of nuclear inclusion. Bar = $550 \mathrm{~nm}$. b) Electron micrograph of spokewheel aggregation of virus particles. Bar $=225 \mathrm{~nm}$. 


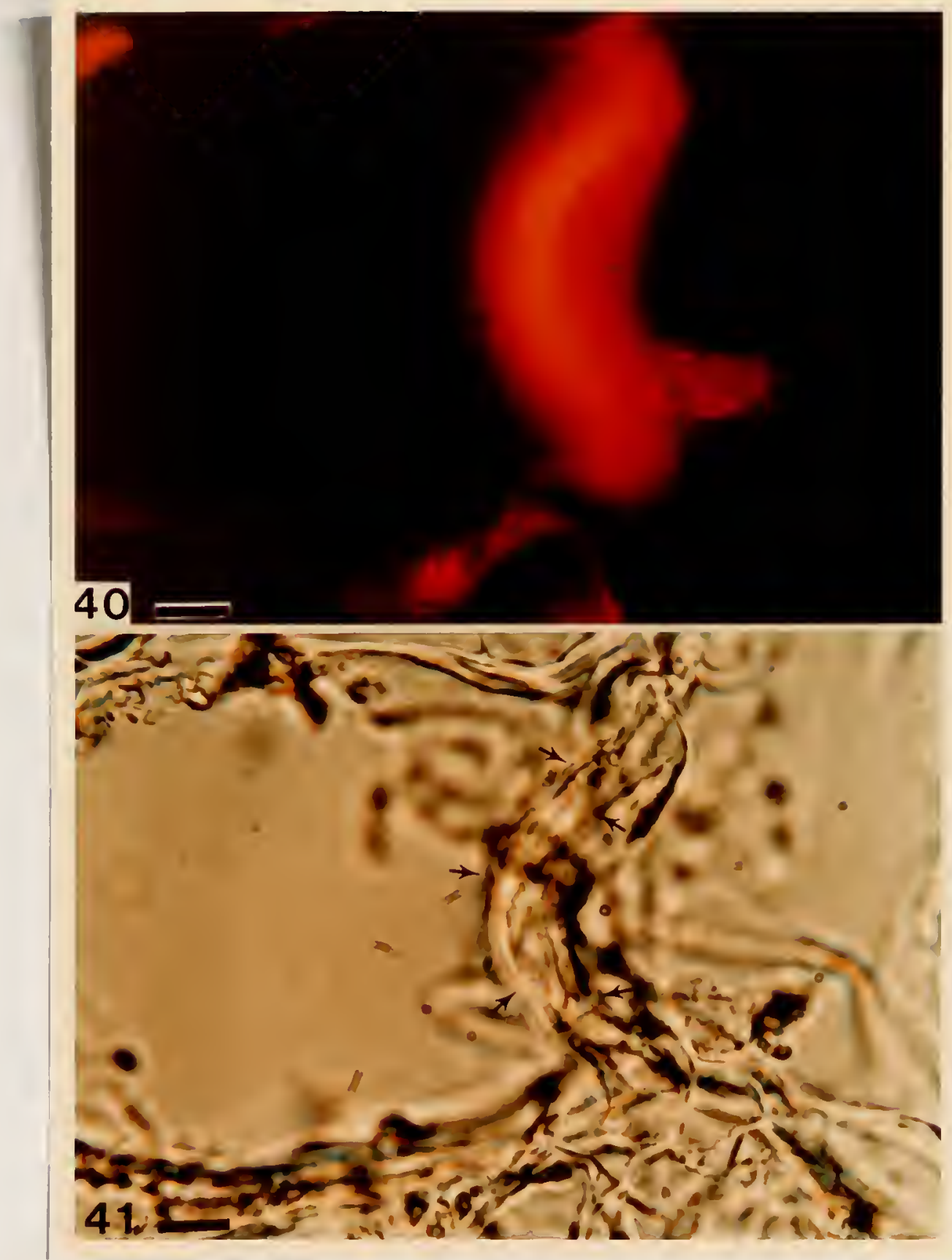

Figure 40. CyMV-infected Cymbidium leaf cells photographed with epifluorescence optics, showing the specific

fluorescence from virus aggregations treated with TRITC-conjugated CYMV antiserum. Bar $=5 \mathrm{\mu m}$.

Figure 41. The same field of Fig. 40 photographed with visible light. Arrows show the location of virus inclusion. Bar $=5 \mathrm{\mu m}$. 


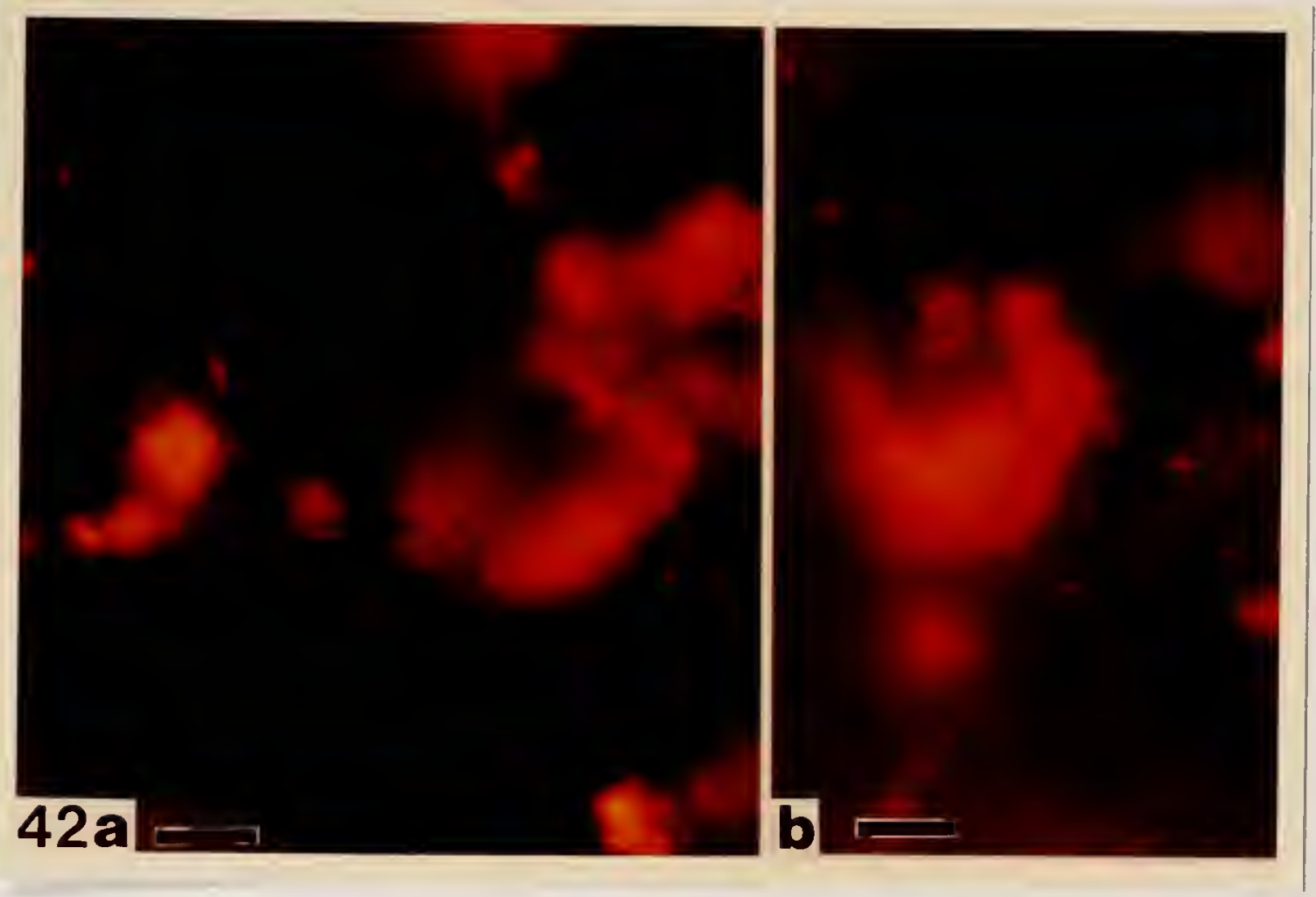

Figure 42. a) and b) CMV-infected Phalaenopsis petal cells photographed with epifluorescence optics, showing the specific fluorescence from irregular crystals treated with TRITC-conjugated CMV antiserum. Bar $=5 \mathrm{um}$. 


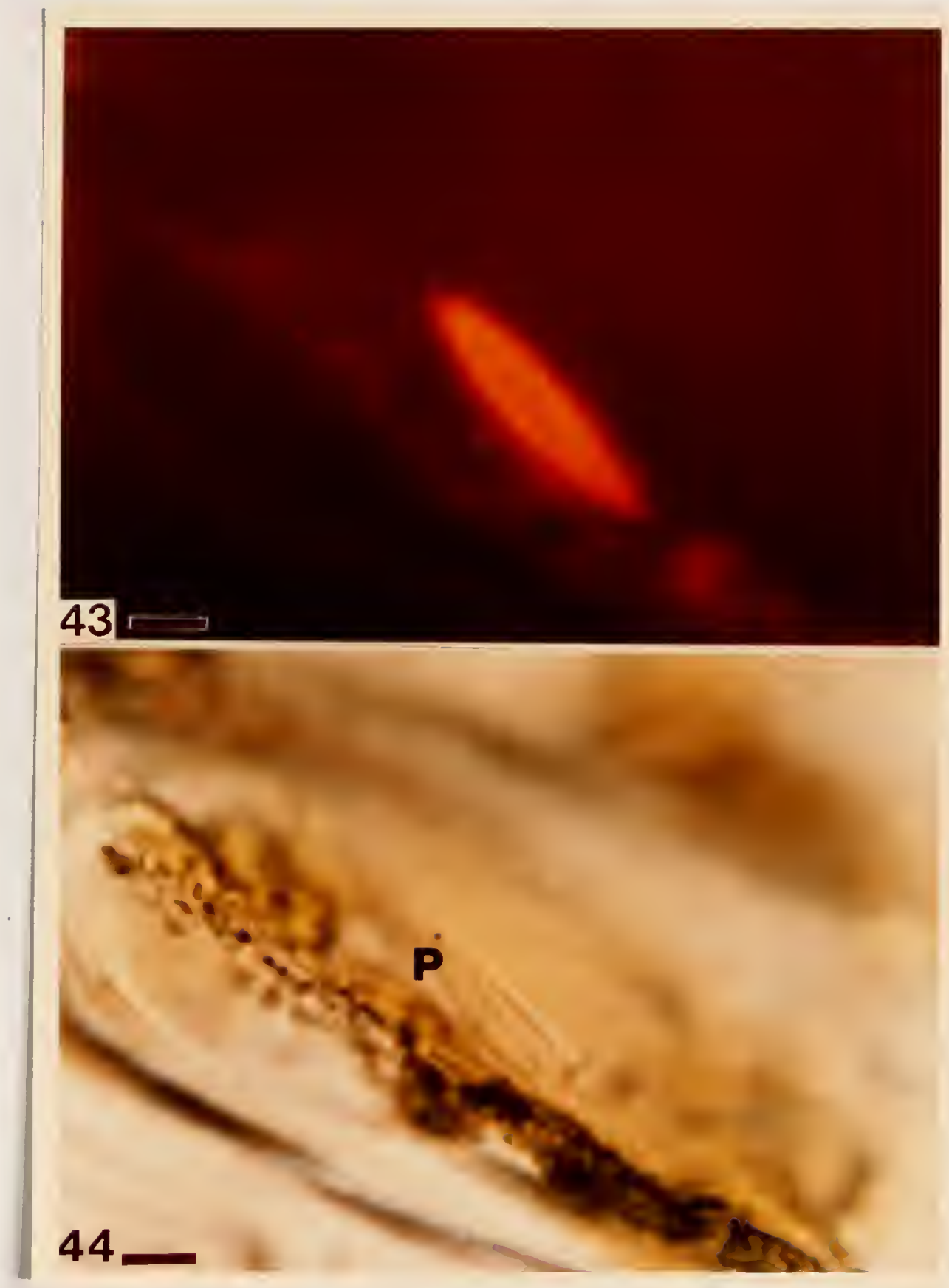

Figure 43. ORSV-infected Cattleya leaf cells photographed with epifluorescence optics, showing the specific

fluorescence from paracrystal treated with TRITC-conjugated ORSV antiserum. Bar = $5 \mathrm{Nm}$.

Figure 44. The same field of Fig. 43 photographed with visible light. P:Paracrystal. Bar = $5 \mathrm{um}$. 


\section{5}

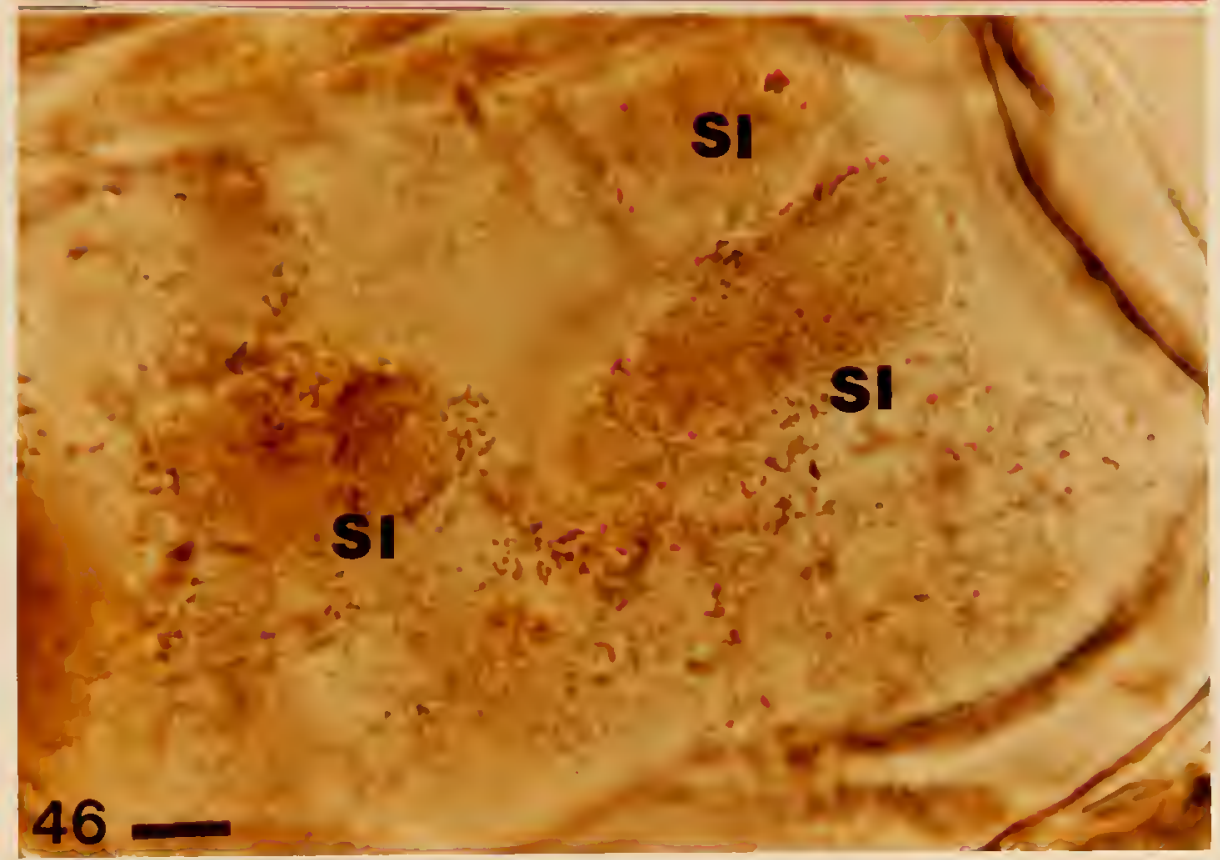

Figure 45. ORSV-infected Cattleya leaf cells photographed with epifluorescence optics, showing the specific fluorescence from stacked-plate inclusions treated with TRITCconjugated ORSV antiserum. Bar $=5$ rm.

Figure 46. The same field of Fig. 45 photographed with visible light. SI:Stacked-plate inclusion. Bar $=5 \mathrm{um}$. 
incubated with TRITC-conjugated pre-immune serum or heterologous antisera.

Protein A-Gold Labelling

Colloidal gold particles, $15 \mathrm{~nm}$ diameter, were selectively labelled on CYMV, ORSV, CMV virions and BYMV cylindrical inclusions in thin sections, which were treated with homologous antisera and protein A-gold complex, respectively (Figs. 47, 48, 49, 51, 53 and 55). Very few gold particles were found on cell components not containing virions or viral inclusions or on intercellular spaces of infected tissue. Likewise, gold particles were not found to be specifically reacted in tissue sections treated with normal serum rather than homologous antiserum, nor were they detected in sections exposed to heterologous antisera (Figs. 50,54 and 56). By this method, virus-like or non-related virus particles are easily distinguished, which is not possible by using conventional thin sectioning techniques. In some orchid cells, for example, some thread-like particles are easily mistaken for CyMV Virions, but these can be differentiated because they do not show any specific gold labeling (Fig. $52)$.

Dilution of antisera affected the non-specific labeling of gold particles. A high concentration of antisera used for incubation resulted in more nonspecific gold labellings (Fig. 47). For this reason, antisera dilutions of $1 / 500$ to $1 / 2000$ were used in this study. 


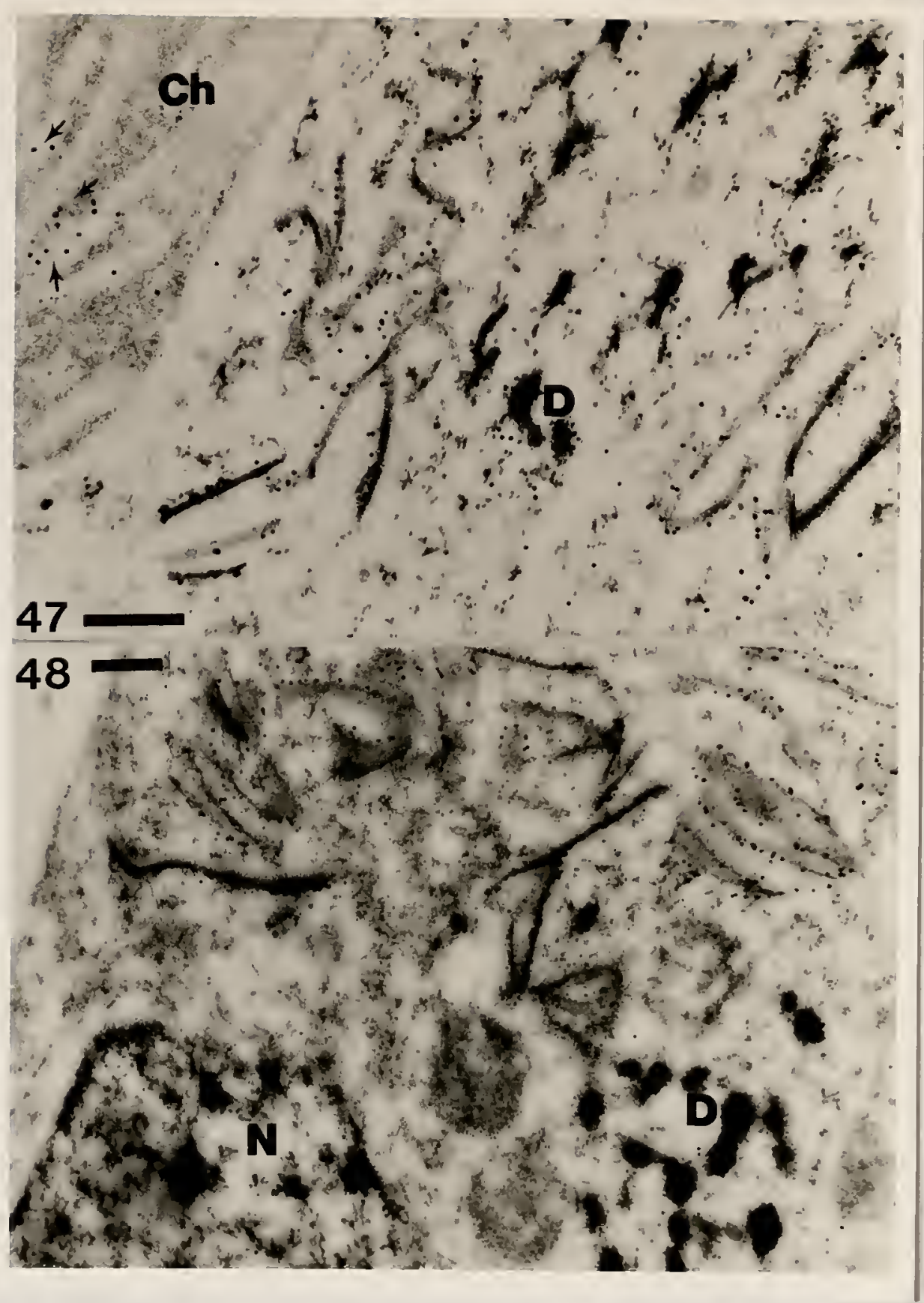

Figure 47. Electron micrograph of BYMV-infected pea leaf cell showing cylindrical inclusions to which gold particles are attached. Arrows show the location of nonspecific reaction where the cylindrical inclusioris are not present. Sections were incubated with antiserum to BYMV cylindrical inclusions ( $1 / 20$ dilution) and labelled with protein A-gold. Ch:Chloroplast, D:Dense body. Bar $=325 \mathrm{~nm}$.

Figure 48. Same tissue and treatments as in Fig. 47, at an antiserum dilution of 1/1000. Note that the gold particles are more specifically associated with the inclusion at this antiserum dilution than shown in Fig. 47. D:Dense body. $\mathrm{N}$ : Nucleus. Bar $=325 \mathrm{~nm}$. 


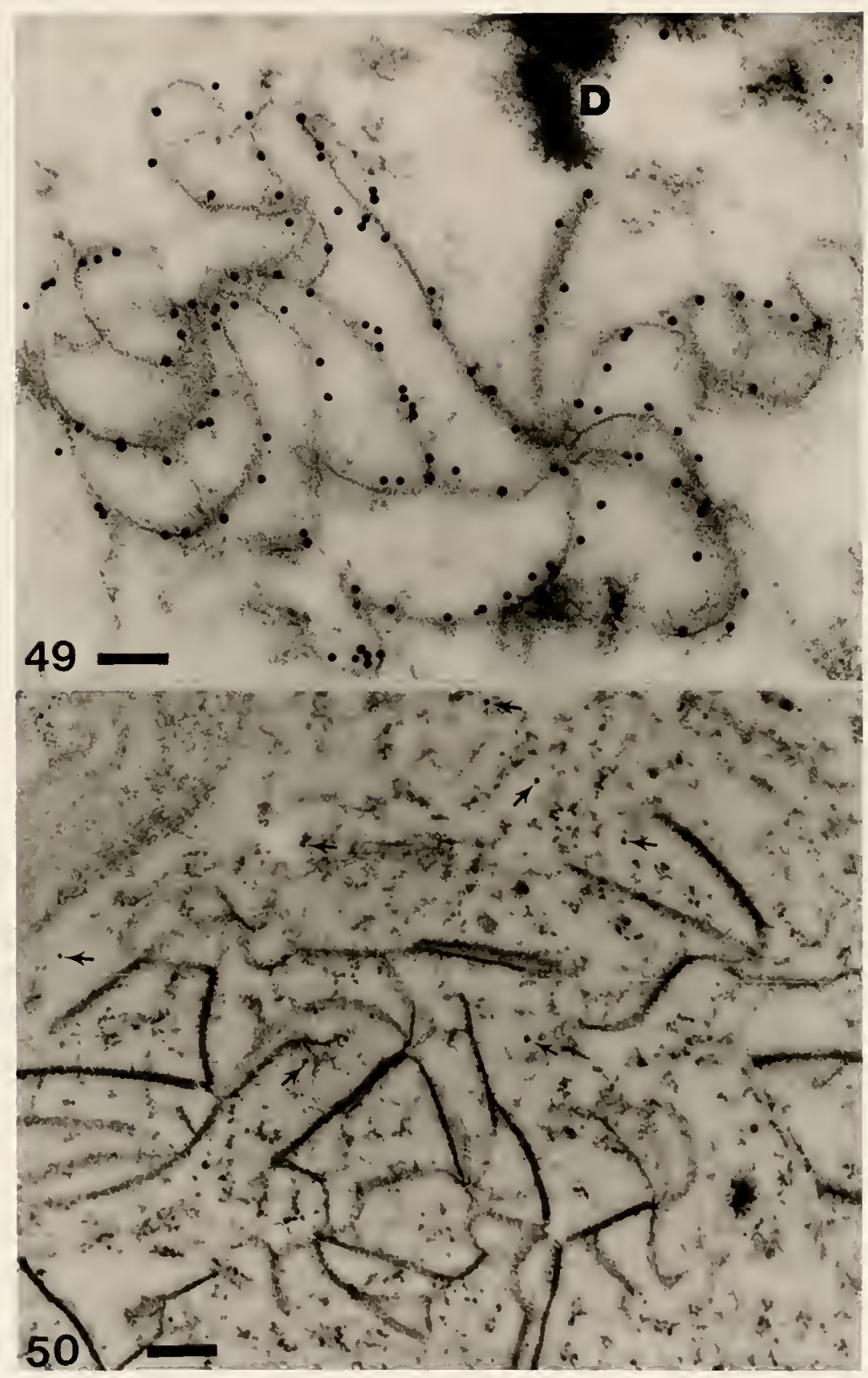

Figure 49. Electron micrograph of pinwheels showing gold particles attached to the arms in higher magnification. Micrograph represents the same tissue and treatments as described in Fig. 48. D: Dense body. Bar $=120 \mathrm{~nm}$.

Figure 50. Same tissue and treatment as in Fig. 49 , except that $1 / 500$ normal serum was used. Arrows showing the locations of non-specific reaction. Bar $=240 \mathrm{~nm}$. 


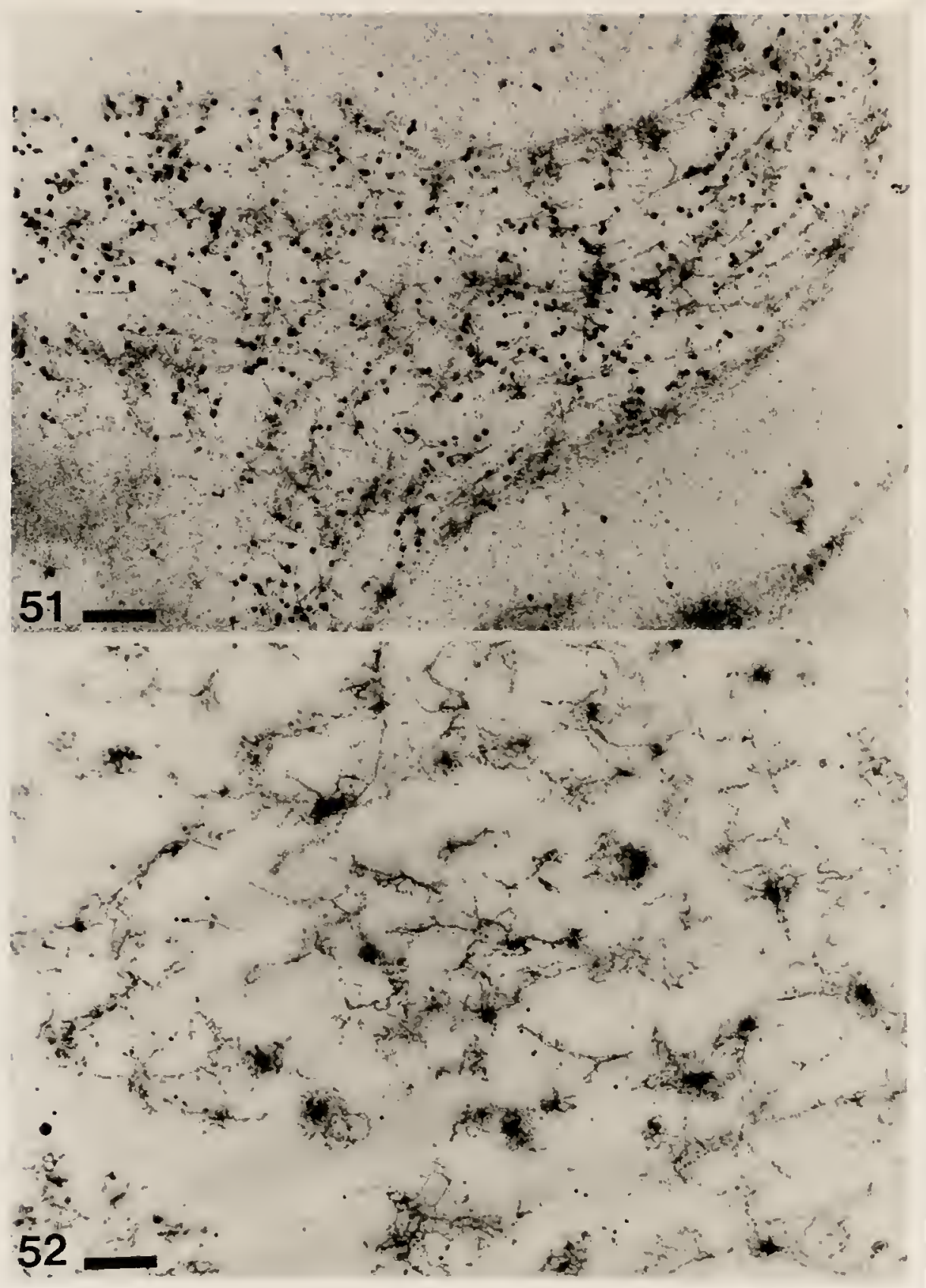

Figure 5l. Electron micrograph of virus aggregations in CyMV-infected Cymbidium leaf cell showing the presence of gold particles on their surface. Section is incubated with CyMV antiserum (1/2000 dilution) and labelled with protein A-gold. Bar $=260 \mathrm{~nm}$.

Figure 52. Electron micrograph of virus-like structures in the same antiserum-treated section as in Fig. 51, but showing no specific reaction. Same treatment as in Fig. 51. Bar $=320 \mathrm{~nm}$. 


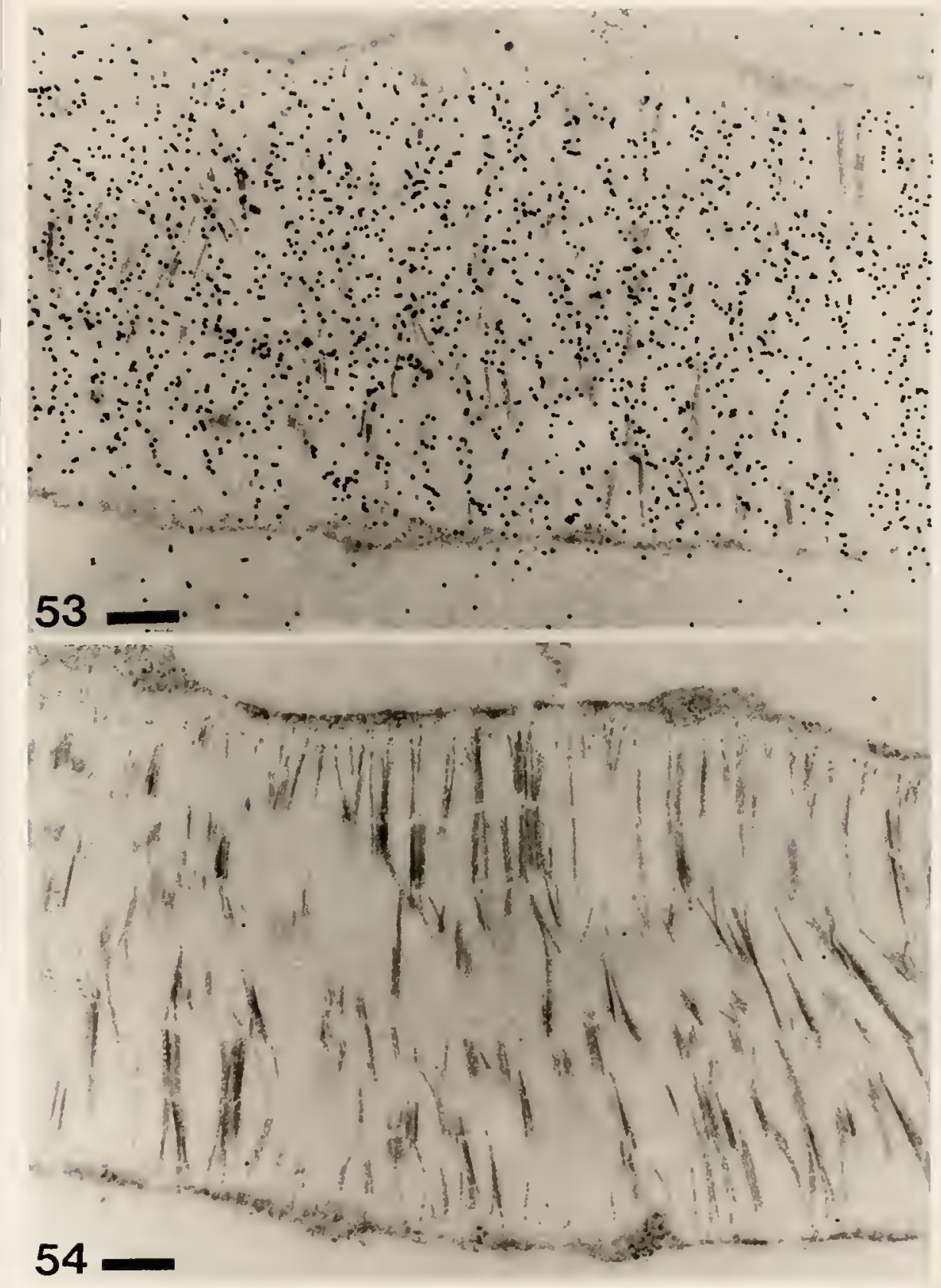

Figure 53. Electron micrograph of virus aggregations of ORSV-infected Cattleya leaf cell showing the presence of gold particles on their surface. Section is incubated with ORSV antiserum (1/1000 dilution) and labelled with protein A-gold. Bar $=300 \mathrm{~nm}$.

Figure 54. Same area as in Fig. 53, except incubation is with CyMV antiserum $(1 / 1000$ dilution $)$. Bar $=300 \mathrm{~nm}$. 


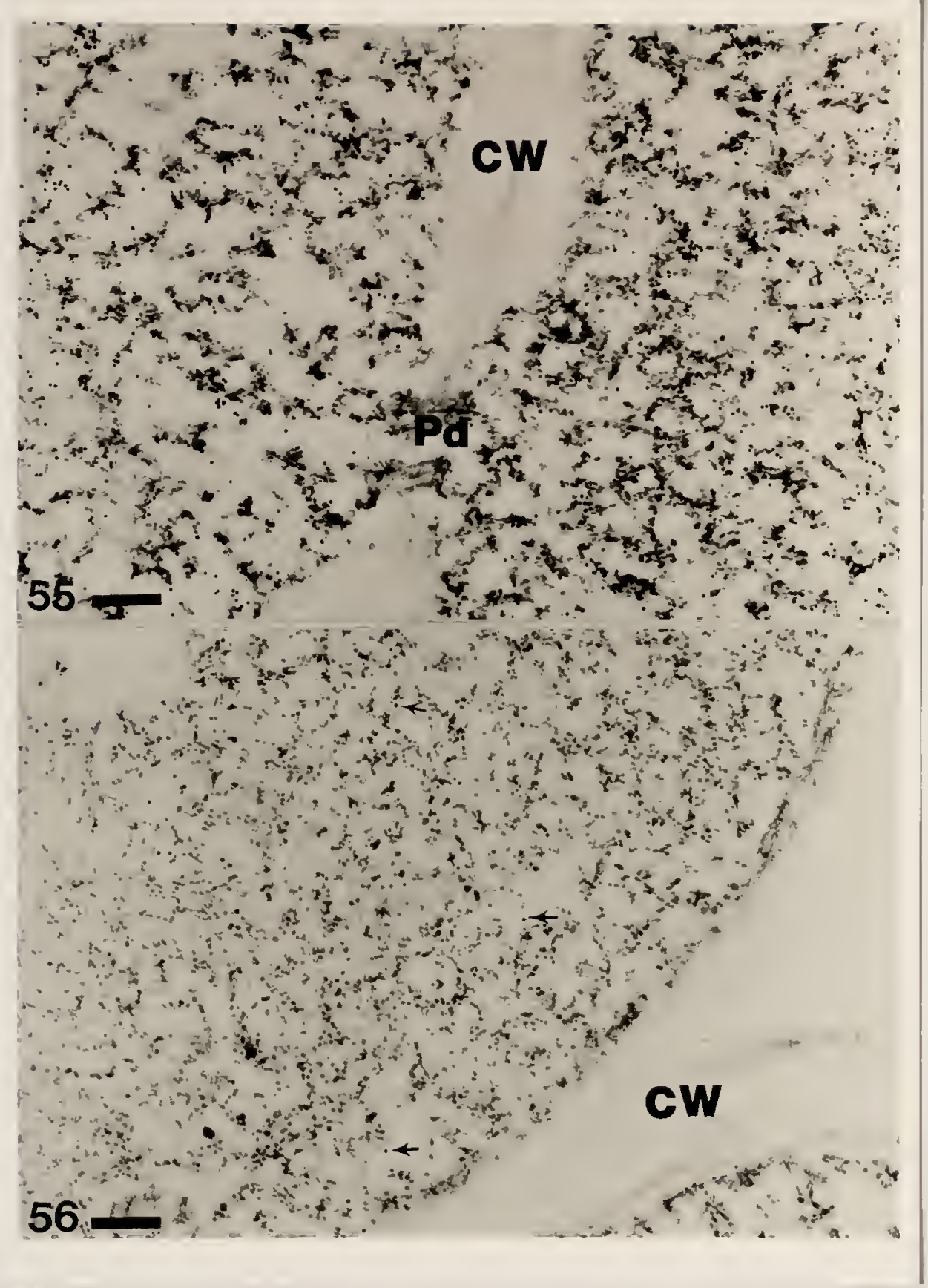

Figure 55. Electron micrograph of virus particles distributed within the cytoplasm of CMVinfected Phalaenopsis leaf cells. Section was incubated with CMV antiserum ( $1 / 1000$ dilution) and labelled with protein A-gold Pd:Plasmodesma. CW:Cell wall. Bar $=350 \mathrm{~nm}$.

Figure 56. Same tissue and treatments as in Fig. 55, except that incubation was with normal serum (1/500 dilution). Note the background of nonspecific reaction (arrows). CW:Cell wall. Bar $=350 \mathrm{~nm}$. 


\section{Discussion}

Negative staining using PTA has been used extensively to detect plant viruses (Hitchborn and Hills, 1965; Doi et al., 1969). However, large grid areas need to be scanned (time-consuming) in checking for the presence of virus particles. VaMo negative staining provides a much more efficient way to detect the infections of CYMV and ORSV and other viruses (Boothroyd and Israel, 1980). Using this method, as little as 6 minutes from grid preparation to examination may be all that is necessary for a diagnosis. The resolution and contrast of the Vamo stain compare favorably with those noted for PTA.

Processing tissues for electron microscopy is extremely labor-intensive. Since virus-induced inclusions are sometimes widely scattered in host tissues, success in locating them by this conventional technique is often limited. The procedure of thin sectioning described here permits electron microscopy of materials selected by light microscopy. For example, Russo et al. (1982) failed to find crystalline inclusions in broad bean true mosaic infected tissues by using electron microscopic methods exclusively. However, and contrary to their conclusions, such inclusions were later found when light microscopic methods were employed (Ko, unpublished). One of the chief 
advantages of light microscopy is the short time required for tissue preparation and the extensive areas that can be scanned. Also, many viruses induce characteristic inclusions which can readily be recognized by this method on the basis of morphology, staining reaction, and location. However, the low resolution of light microscopy is a major limiting factor in the interpretations of the inclusions seen by this method. The $O / G$ and toluidine blue methods described in this study provide the solution to this problem, since the same $(O / G)$ or adjacent (toluidine blue) sections can be examined by both light and electron microscopy. The $O / G$ was less satisfactory for this purpose, since the fine structures of cells and inclusions were adversely affected by its staining process. Therefore, the toluidine blue method was used in this study to reveal the fine structure of inclusions. In this study, orchid infections caused by ORSV, CYMV, CMV, BYMV and the Brassia rhabdovirus were readily studied by this approach. Toluidine blue is not a selective dye, however, it facilitates locating the inclusion-containing areas for ultrathin sectioning.

Fluorescent antibodies have been used extensively in studying animal virus infections. However, their use in the study of plant viruses has been very limited. This is partly because the removal of non-specific staining of plant tissues by fluorescent conjugates is very difficult, 
and standard absorption procedures are inadequate. In some cases, the bright autofluorescence of lignified cell walls of certain tissues interferes with observation and photography of specific fluorescence in tissues. Yet another problem in this procedure is that it is difficult to obtain satisfactorily thin ( $15 \mu \mathrm{m}$ or below) sections of plant tissues. In this study, non-specific staining was eliminated by incubating TRITC-conjugated antisera with healthy tissue extracts before staining infected tissues. With healthy tissue extracts and conjugated antibody prepared in advance, the procedure from diseased plant to microscopic examination can be completed in less than 2 hours. This is much shorter than the time required for the immunofluorescence procedures described by others (Mumford and Thornley, 1977; Nishiguchi et al., 1980; Rao et al. , 1978).

Ferritin and colloidal gold labelled antibodies are the most common probes used for localization at the electron microscopic level (Gildow, 1982; Martelli and Russo, 1984; Baker et al., 1985). Labelling of ultrathin sections with colloidal-gold conjugated antibodies is generally accomplished with less nonspecific binding than when ferritin is used (De Mey, 1984; Baker et al., 1985). In animal virology, several studies have been performed using the protein A-gold approach in order to trace the place of synthesis, the post-translational glycosylation, 
and the pathway taken by specific viral proteins in infected cells (Green et al., 1981; Griffiths et al..' 1982, 1983). It has also been used to reveal the antigenic sites in different cellular compartments of infected cells (Garzon et al., 1982; Roth, 1983, 1984). These studies have demonstrated that the protein A-gold technique represents a valuable approach for medical diagnosis (Garzon et al., 1982). It has also been introduced as an alternative to other techniques for the ultrastructural localization of antigenic sites (Bendayan, 1984). In plant virology, immunogold labelling was first applied to barley stripe mosaic virus by using goldimmunoglobulin (IgG) complexes for Lowicryl-embedded tissues (Lin and Langenberg, 1983). It was also used to identify viral antigens in suspensions (Giunchedi and Langenberg, 1982; Lin, 1984; Louro and Langenberg, 1984). However, some complexity is involved in using Lowicryl and the gold-IgG complex (Causton, 1984; Newman and Jasani, 1984, Louro and Lesemann, 1984). The problems associated with the use of Lowicryl can be circumvented by using LR White resin instead. The polymerization of LR white does not require the very low temperatures and ultraviolet light necessary for the polymerization of Lowicryl (Causton, 1984). This study demonstrates that the higher temperature for polymerization of LR white does not interfere with the specificity of immunogold labelling 
for orchid viruses. The time period for the polymerization of LR White is also much shorter than for Lowicryl. In addition, this embedding medium possesses another advantage of being very easy to use.

The protein A-gold technique is simple, sensitive, reliable, and gives specific labelling of high resolution. When compared with other immunocytochemical techniques, it has repeatedly provided superior results (Bendayan, 1984; Beesley et al., 1982). It also displays several advantages: antibodies raised in different mammalian species can be used; the preparation of colloidal gold and the formation and purification of the protein A-gold complex are quite simple procedures; and the use of gold particles as the electron-dense marker allows for easy identification of the labelled structures, and makes the technique suitable for double labellings (Roth, 1983). The reliability of the technique and its wide range of applications in electron microscopy have been clearly demonstrated (Bendayan, 1984). It is usually very difficult to identify the spherical virus particles scattered within the cells in ultrathin sections. This study has shown that with the immunogold technique, spherical virus particles can be differentiated. In BYMVinfected pea tissues, there are some thin plate inclusions which may be misidentified as BYMV cylindrical inclusions. The composition of thin plates cannot be recognized by 
conventional electron microscopy of thin sections.

However, they can be differentiated from cylindrical inclusions by gold labelling without any difficulty.

Thin sectioning, VaMo negative staining,

immunofluorescence microscopy, and protein A-gold labelling

described in this chapter confirmed that light microscopy was an accurate and useful method for detecting orchid viruses. 


\section{CHAPTER 4 \\ CONCLUSIONS}

Light microscopy using the Azure $A$ and $O / G$ stain was shown to be a useful diagnostic tool for some orchid viruses. For orchid viruses which cannot be detected by conventional methods (bioassay, leaf dip electron microscopy and/or serology), this technique is the only practical alternative for this purpose. It also has the advantage of being fast and inexpensive. It is an important technique for developing countries which cannot afford expensive facilities. In addition to diagnosis, this technique is very useful in the selection of tissues for ultrathin sectioning, for monitoring viral inclusion purification, and the selection of antisera for identifying the specific level of viruses (Christie and Edwardson, 1977; Hiebert et al., 1984).

Orchids posed several problems which had to be overcome to make the light microscope techniques successful. For thick-leaved orchids, paradermal sections could be conveniently made, whereas, for thin-leaved orchids, sandpaper abrasion was preferable to expose cells for staining. For instances where cell walls were exceptionally thick, heating at $60^{\circ} \mathrm{C}$ was necessary to 
facilitate stain penetration in ORSV-infected tissues. ORSV, unlike other tobamoviruses, required a longer period of heating to facilitate Azure A stain penetration of virus aggregates. Rhabdoviruses infecting Brassia and Cymbidium required heating at $60^{\circ} \mathrm{C}$ and treatment in Triton $\mathrm{x}-100$ to facilitate staining inclusions contained within the nucleus. Presently, this is the only practical technique to detect the rhabdovirus infection. Since rhabdoviruses have been considered as important as ORSV and CyMV (Lesemann and Marwitz, 1983), light microscopy could be an important tool for their detection.

Interpretation of the light microscopy results was facilitated by the development of the electron microscopic techniques improvised for this research. The same inclusions seen in tissues stained with $O / G$ or toluidine blue for light microscopic examination were also observed by electron microscopy. The viral nature of inclusions seen by light microscopy was also confirmed by in situ examination of tissues directly labelled with TRITCconjugated antisera or indirectly using protein A-gold. Nonspecific antibody binding was eliminated in fluorescence microscopy by pre-incubating TRITC-conjugated antisera with healthy tissue extracts.

Immunogold labelling has been used to identify the viruses in ultrathin sections (Lin and Langenberg, 1983) and leaf dips (Louro and Lesemann, 1984; Lin, 1984). In 
addition to providing confirmatory data regarding the viral nature of inclusions, this procedure is potentially valuable for the in situ examination of viruses occurring in low titers, and distinguishing viral from non-viral intracellular structures. As shown in this study, the procedure proved useful for capsid and nonstructural proteins.

LR White resin was suitable for embedding tissues infected with plant viruses. The use of this resin facilitated immunogold labelling studies considerably because it is much less labor intensive than the previously used resins, such as epoxy resin or even Lowicryl resin.

Another labor-saving improvisation developed in this study was a multi-grid staining apparatus involving simple equipment available in all reasonably equipped scientific laboratories. The device could house at least 10 grids simultaneously for staining and processing for electron microscopy without individual handling of the grids.

VaMo was an effective negative stain for orchid viruses in leaf dip diagnosis. This stain promoted the congregation of virions to the edge of the droplet on the grid. Therefore, only the droplet edge needed to be scanned in the electron microscope. The stain contrast and resolution of Vamo compared favorably with that of 
PTA, and its use is therefore to increase the accuracy of orchid virus diagnosis, while reducing the time needed for scanning at the same time.

A labor-saving procedure useful for ORSV and CyMV bioassay to indicator plants was also developed. The technique obviates the need for using a mortar and pestle for trituration and thereby is much more convenient to the specific indexing needs for orchid growers, who must index numerous samples. 


\section{APPENDIX I \\ A SIMPLIFIED BIOASSAY TECHNIQUE FOR \\ CYMBIDIUM MOSAIC AND ODONTOGLOSSUM RINGSPOT VIRUSES}

Although there are a number of advanced techniques available to detect orchid viruses, bioassay still remains a popular, inexpensive, and reasonably reliable technique for detecting Odontoglossum ringspot (ORSV) and Cymbidium mosaic (CYMV) infections (Lawson and Ali, 1975; Lawson and Brannigan, in press; Wisler and Zettler, in press; Zettler et al., 1984). Gomphrena globosa. is the laboratory indicator plant for ORSV while Cassia occidentalis is used for CyMv.

In the normal bioassay method, clean mortar and pestles are used to extract juice from the orchid leaf sample, often in the presence of a buffer solution (Lawson and Ali, 1975; Lawson and Brannigan, in press). This juice is then rubbed onto the leaves of indicator plants, which have previously been dusted lightly with a fine abrasive (usually 300-600 mesh Carborundum). The abrasive produces microscopic wounds which facilitate entry of the virus particles into the inoculated leaves. To avoid carry-over of inoculum, the mortar and pestle must be thoroughly cleaned (preferably sterilized) between samples. 
Recent studies have shown that the time-consuming step of using a mortar and pestle can readily be circumvented by using a razor blade incision to obtain inoculum. The new technique is relatively easy. A razor blade is used to slice the leaf sample just below and parallel to the leaf surface, thereby exposing wounds about $3.0 \mathrm{~cm}^{2}$. Immediately after cutting, the wounded orchid leaf surfaces can be gently rubbed by hand onto the leaves of indicator plants. If the wounded surfaces are dry, they can be misted slightly with water before inoculation. As in juice inoculations, the leaves of indicator plants should be rubbed firmly but gently to prevent damage, which could interfere with test results.

Most assayists rub the two cotyledonary leaves (or the first set of true leaves) of young Cassia seedlings, whereas for Gomphrena, the fifth or sixth pairs of true leaves are inoculated. A fresh cut of the orchid leaf sample should be made for each Cassia cotyledon or Gomphrena leaf rubbed to assure an abundant supply of inoculum. Before proceeding to the next orchid sample, a fresh razor blade or an old one that has been sterilized should be used. Sterilization can be done conveniently by dipping the razors into $70 \%$ ethanol and flaming them. After inoculations, excess orchid leaf juice and Carborundum can be gently rinsed from the inoculated leaves with water. As might be expected, symptoms observed on indicator plants inoculated by the razor blade method are 
identical to those resulting from the mortar and pestle method, described previously (Lawson and Ali, 1975; Lawson and Brannigan, in press). Discrete dark brown localized lesions are typical of CyMv infections on Cassia cotyledons, whereas the lesions induced by ORSV on Gomphrena leaves are light tan in color. The lesion number in different tests will vary according to the virus concentration in the orchid sample, the condition of the indicator plants, and the skill of the inoculator. Results can be recorded about one week after inoculation if greenhouse temperatures are between $80-90^{\circ} \mathrm{F}$. At lower temperatures, slightly longer times may be required.

Both the razor blade and the mortar and pestle techniques are reasonably reliable methods of virus transmission. In a comparative test involving 16 Cassia and 6 Gomphrena seedlings inoculated by each method, an average of 12 lesions/Cassia cotyledon and 74 lesions/Gomphrena leaf were recorded when razor blades were used in comparison to 5 lesions/Cassia cotyledon and 43 lesions/Gomphrena leaf for the other method. The razor blade technique is recommended as a convenient assay method for ORSV and CYMV, especially when large numbers of orchid samples must be indexed. However, such recommendations cannot be made for some of the other viruses known to infect orchids. This is particularly true of those viruses which may occur in low concentrations in their orchid hosts or cannot be transmitted by rub-inoculation (e.g., the Cypripedium filamentous and Masdevallia isometric viruses) 
(Lawson and Brannigan, in press). Orchidists inexperienced at rub-inoculation should include a few noninoculated Cassia and Gomphrena seedlings in their controls. Sometimes other factors, such as pollution damage, can induce lesions on Cassia or Gomphrena plants which can be confused with those caused by virus (Lawson and Brannigan, in press). Inoculating some indicator plants with an orchid sample known to be free of virus is recommended so that possible inoculation damage can be distinguished from viral lesions. 


\section{APPENDIX II}

AN EFFICIENT PROCEDURE FOR STAINING LARGE NUMBERS

OF ELECTRON MICROSCOPE GRIDS

This paper describes a simple tubular device which can be used to stain large numbers of electron microscope grids simultaneously. Staining and rinsing of ultrathin sections mounted on individual grids are time-consuming and tedious if grids are handled individually according to the usual techniques recommended for electron microscopy (Hayat, 1970 ). In addition, the repeated use of forceps may damage the support films and grids. Therefore, several attempts have been made for simultaneous staining of many grids (Chen, 1973; Fisher, 1972; Godkin, 1977; Gorycki, 1978; Hiraoka, 1972; Robertson and Roberts, 1971). However, most of these devices are either difficult to construct or use.

These studies revealed that any polyethylene tubing with an exterior diameter of $3 \mathrm{~mm}$ can be used. Tubes such as those found in ordinary commercial ball-point pens (with an interior diameter of $1.5 \mathrm{~mm}$ ) were most satisfactory for this purpose. All it requires is that a few holes must be cut into the tubing so that grids can be inserted and anchored while being stained and rinsed (Fig. 57). The diamond-shaped and circular holes are made using a needle-point scalpel. The tubes should be 
thoroughly cleaned before inserting the grids. The polyethylene tube is then placed into a glass tube $13.5 \mathrm{~mm}$ interior diameter).

To retain their proper orientation, the grids are carefully inserted, one at a time, into the polyethylene tube as it is being placed into the glass tube. When in place, and prior to staining, grids are moistened by rinsing them 5-10 seconds in deionized water. Rinsing can be accomplished by using an intravenous set (e.g., IV Set, McGaw Laboratories, Inc., Sabana Grande, Puerto Rico 00747) to supply a jet of water sufficiently fine to enter the glass and polyethylene tubes (Fig. 58). After rinsing, excess water can be eliminated from the tubes by gently tapping the tubes on a solid surface covered with filter paper or shaking them by hand. For staining, the tubes are attached to a $2 \mathrm{ml}$ pipette pump (pi. pump 2000, Glasfirn Giessen, D 6300 Giessen, West Germany) (Fig. 59). As fluids are drawn up into the glass tube, care should be taken to avoid air bubbles possibly present on the grids.

These staining and rinsing devices have been used successfully for over one year. The tubes can be reused, but must be cleaned thoroughly between operations. Labs using this technique are able to handle many grids simultaneously. In our experience, the grid holder provides a simple, efficient way for staining thin sections and has reduced mechanical damage and contamination of thin sections. 


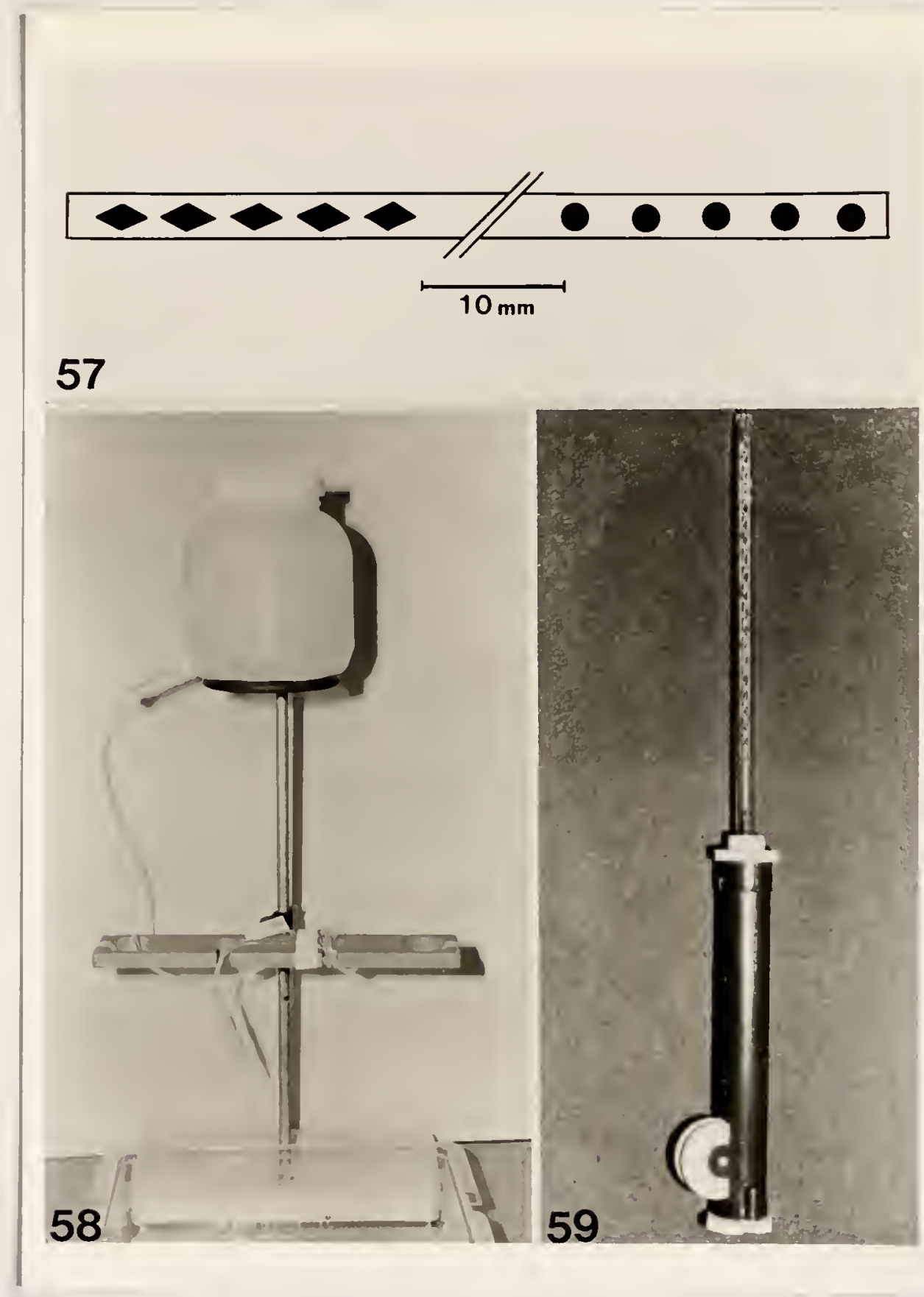

Figure 57. Diagram of polyethylene tube showing the side for insertion of grids through diamondshaped openings (left). The grids are anchored in the small round holes directly beneath the diamond-shaped holes (right reverse side of tube).

Figure 58. Intravenous set used to rinse grids contained within polyethylene tube.

Figure 59. Two ml pipette pump used to apply stains to grids. 
APPENDIX III

COMPARATIVE DIAGNOSES OF ORCHID VIRUSES

BY LIGHT MICROSCOPY, ELECTRON MICROSCOPY, AND SEROLOGY

Diagnostic Methods*

Orchid

Samples

(Genus)
Foliar

Symptoms
Light

Microscopy
Electron

Microscopy
Serology

CYMV, ORSV CYMV, ORSV
CYMV, ORSV

Necrosis

$\mathrm{NE} * \star$

$\mathrm{NE}$

Mottle

Mottle

Mottle

Mottle

Mottle

Mottle

Chlorosis

Chlorosis \&

Necrosis

Chlorosis \&

Necrosis

$\mathrm{NE}$

Mottle \&

Necrosis

odontocidium

Oncidium

odontoglossum

Cattleya

Phalaenopsis

Vanilla

Cattleya

Vanilla

Cattleya

Phal aenopsis

Cattleya

Encyclia

Phalaenopsis

Vanda
Oncidium
Mottle

Mottle \&

Necrosis

Mottle

Mottle

$\mathrm{NE}$

$N E$

Mottle

$\mathrm{NE}$

$N E$

$N E$

$\mathrm{NE}$

Necrosis

Mottle

NE

NE
CYMV

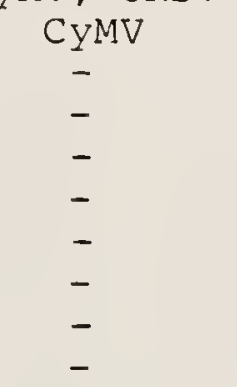

Rhabdovirus

Rhabdovirus

Rhabdovirus

Rhabdovirus

Rhabdovirus<smiles>[TlH3]</smiles>

CyMV

CyMV

CyMV

Rhabdovirus

ORSV

CYMV,

Potyvirus

Rhabdovirus

CyMV

CYMV, ORSV

Potyvirus

ORSV

ORSV

CYMV

CYMV

CYMV, ORSV

Potyvirus

Potyvirus
CyMV

CyMV

CyMV

CYMV

CyMV

CYMV, ORSV

$-$

$-$

-

$-$

$$
-
$$

CyMV

-

-

ORSV

CYMV

CYMV

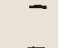

CYMV

CYMNV

CYMV

CYMV, ORSV

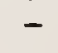

-

ORSV

CYMV

CYMV
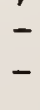

ORSV

ORSV

CYMiV

CYMV, ORSV CYMV, ORSV
CYMV, ORSV 
*For light microscopy, Azure $A$ and $O / G$ stains were used (see chapter 2). For electron microscopy, 2\% potassium phosphotungstate ( $\mathrm{pH} 6.9$, containing $0.025 \%$ bacitracin) was used for negative stain. For serology, the SDS immunodiffusion test as described by Wisler et al. (1982) was used. The CMV, ORSV, and CYMV antisera were as described in chapter 3 . The BYMV capsid and nuclear inclusion antisera used were obtained from C. -A. Chang.

**NE: Non-evident symptom. 


\section{LITERATURE CITED}

Anonymous. 1978. Dollars and sense of orchid growing. Malaysian Business, June, 1978. P. 9-24.

Anonymous. 1983. Ornamental Horticulture Committee Reports: Florida Agriculture in the 80's. P. 13-24, Univ. of Florida, Institute of Food and Agricultural Sciences, Gainesville, Florida. March 1983.

Baker, K. K., P. C. Ramsdell, and J. M. Gillett. 1985 . Electron microscopy: Current applications to plant virology. Plant Dis. 69:85-90.

Beesley, J. E., A. Orpin, and C. Adlam. 1982. A comparison of immunoferritin, immuno-enzyme and gold-labeled protein A methods for the localization of capsular antigen on frozen thin sections of the bacterium, Pasteurella haemolytica. Histochem. J. 14:803-810.

Bendayan,H M. 1984. Protein A-gold electron microscopic immunocytochemistry: Methods, applications and limitations. J. Electron Microscopy Technique 1:243-270.

Boothroyd, C. W., and H. W. Israel. 1980. A new mosaic disease of corn. Plant Dis. 64:218-219.

Causton, B. E. 1984. The choice of resins for electron immunocytochemistry. P. 29-36, in: Immunolabelling for Electron Microscopy. J. M. Polak and I. M. Varndell, eds. Elsevier Science Pub. Co. Inc., New York.

Chang, M. U., K. Arai, Y. Doi, and K. Yora. 1976. Morphology and intracellular appearance of orchid fleck virus. Ann. Phytopathol. Soc. Japan 42:156-167.

Chen, M.-H. 1973. An automatic device for staining and washing ultrathin sections. Stain Technology 48:261263.

Chen, M.-H., D. V. Rao, and C. Hiruki. 1983. Electron microscopy of Datura stramonium infected with Cymbidium mosaic virus. Int. J. Tropical Plant Dis. 1:87-9l. 
Christie, R. G., and J. R. Edwardson. 1977. Light and electron microscopy of plant virus inclusions. Fla. Agr. Exp. Sta. Monograph Series No. 9. 150 pp.

Corbett, M. K. 1974. Detection of viruses and diagnosis of plant viral diseases by electron microscopy. Acta Hort. $36: 141-188$.

De Mey, J. 1984. Colloidal gold as marker and tracer in light and electron microscopy. EMSA Bull. 14:54-66.

Doi, Y., S. Toriyama, K. Yora, and M. Asuyama. 1969. Direct negative staining method for detecting virus particles in fresh preparations from infected plant tissues. Ann. Phytopathol. Soc. Japan 35:180-187.

Dressler, R. L. 1981. The Orchids. Natural History and Classification. Harvard University Press, Cambridge, Massachusetts. 332 pp.

Edwardson, J. R. 1974. Some properties of the potato virus-Y group. Fla. Agr. Exp. Stn. Monograph Series 4.. 398 pp.

Edwardson, J. R., and R. G. Christie. 1978. Use of virusinduced inclusions in classification and diagnosis.

Annu. Rev. Phytopathol. 16:31-55.

Edwardson, J. R., and R. G. Christie. 1979. Light microscopy of inclusions induced by viruses infecting peppers

(Capsicum annuum). Fitopatologia Brasileira 4:341-373.

Edwardson, J. R., and F. W. Zettler. In press. Odontoglossum ringspot virus. In: The Rod-Shaped Plant Viruses. M. H. V. Van Regenmortel, ed. Plenum Press Co. Inc., New York.

Fisher, D. G. 1972. A holder for simultaneous fluid processing or carbon coating of electron microscope grids in lots of 10 or more. Stain Technology 47:235-238.

Garzon, S. M. Bendayan, and E. Kurstak. 1982. Ultrastructural localization of viral antigens using the protein Agold technique. J. Virol. Methods 5:67-73.

Gildow, F. E. 1982. Coated-vesicle transport of luteoviruses through salivary glands of Myzus persicae. Phytopathology 72:1289-1296. 
Giunchedi, L., and W. G. Langenberg. 1982. Efficacy of colloidal gold-labelled antibody as measured in barley stripe mosaic virus-lectin-antilectin system. Phytopathology 72:645-647.

Godkin, S. E. 1977. Improved staining boxes for fast uniform staining of ultrathin sections on grids. Stain Technology 52:265-267.

Gorycki, M. A. 1978. An efficient staining method for ultrathin sections. Stain Technology 53:11-15.

Green, J., G. Griffiths, D. Louvard, P. Quinn, and G. Warren. 1981. Passage of viral membrane proteins through the Golgi complex. J. Mol. Biol. 152:663-698.

Griffiths, G., R. Brands, B. Burke, D. Louvard, and G. Warren. 1982. Viral membrane proteins acquire galactose in trans Golgi cisternae during intracellular transport. J. Cell Biol. 95:781-792.

Griffiths, G., P. Quinn, and G. Warren. 1983. Dissection of the Golgi complex. I. Monensin inhibits the transport of viral membrane proteins from medial to trans Golgi cisternae in baby hamster kidney cells infected with Semliki forest virus. J. Cell Biol. 96:835-850.

Hamilton, R. I., J. R. Edwardson, R. I. B. Francki, H. T. Hsu, R. Hull, R. Koenig, and R. G. Milne. 1981. Guidelines for the identification and characterization of plant viruses. J. Gen. Virol. 54:223-241.

Hammond, J., and R. Hull. 1983. Plantain virus X. C.M.I./ A.A.B., Kew, Surrey, England. Descriptions of Plant Viruses No. 266.

Hanchey, P., C. M. Livingston, and F. B. Reeves. 1975. Cytology of flower necrosis in Cattleyas infected by Cymbidium mosaic virus. Physiol. Plant Path. 6:227-231.

Hayat, M. A. 1970. Principles and Techniques of Electron Microscopy: Biological Applications. Vol. l. Van Nostrand Reinhold Co. Inc., New York. 412 pp.

Herbert, D. C., F. J. Weaker, and P. J. Sheridan. 1982. Evaluation of the ability of Tween 80 , dimethylsulphoxide and Triton $\mathrm{x}-100$ to enhance immunocytochemical staining of autoradiograms. Histochem. J. 14:161-164. 
Hiebert, E., D. E. Purcifull, and R. G. Christie. 1984. Purification and immunological analyses of plant viral inclusion bodies. P. 225-280, in: Methods in Virology. Vol. 8, K. Maramorosch and H. Koprowski, eds. Academic Press, New York.

Hiraoka, J.-I. 1972. A holder for mass treatment of grids adapted especially to electron staining and autoradiography. Stain Technology 47(6):297-301.

Hiruki, C., M. M. Chen, and D. V. Rao. 1980. Ultrastructure of Cattleya leaf cells infected with Cymbidium mosaic virus. Acta Hort. 110:273-279.

Hitchborn, J. H., and G. J. Hills. 1965. The use of negative staining in the electron microscopic examination of plant virus in crude extracts. Virology 27:528-554.

Hollings, M., and O. M. Stone. 1977. Cymbidium ringspot virus. C.M.I./A.A.B., Kew, Surrey, England. Description of Plant Viruses No. 178 .

Hollings, M., O. M. Stone, and R. J. Barton. 1977. Pathology, soil transmission and characterization of cymbidium ringspot, a virus from Cymbidium orchids and white clover (Trifolium repens). Ann. App. Biol. $85: 233-248$.

Inouye, N. 1977. Serological diagnosis method for Cymbidium mosaic virus and Odontoglossum ringspot virus in orchids. Nogaku Kenkyu 56:1-13.

Ko, N.-J., and M.-J. Chen. 1982. Modified triple stain for ultrathin sections. Proc. 3rd Republic of China symp. Electron Microscopy. April 15, Taipei, Taiwan, p.17-18.

Kuwite, C. A., and D. E. Purcifull. 1982. Some properties of a cucumber mosaic virus strain isolated from winged bean in Florida. Plant Dis. 66:1071-1073.

Lawson, R. H., and S. Ali. 1975. Orchid viruses and their detection by bioassay, serology and electron microscopy. P. 62-103, in: Amer. Orchid Soc. Handbook on Orchid Pests and Diseases. Amer. Orchid Soc., Inc., Cambridge, Massachusetts.

Lawson, R. H., and M. Brannigan. In press. Virus diseases of orchids, in: Amer. Orchid Soc. Handbook on Orchid Pests and Diseases. Amer. Orchid Soc., Inc., West Palm Beach, Florida. 
Lawson, R. H., and S. S. Hearon. 1974. Distribution and staining properties of Cymbidium mosaic virus in buds of Cattleya orchids. Acta Hort. 36:195-204.

Lawson, R. H., and K. Horst. 1984. Tests help prevent viruses in orchids. Greenhouse Manager July. P. 102108.

Lesemann, D. E. 1977. Long, filamentous virus-like particles associated with vein necrosis of Dendrobium phalaenopsis. Phytopathol. Z. 89:330-339.

Lesemann, D. E., and J. Begtrup. 1971. Electronenmikroskopischer Nachweis eines bazilliformen Virus in Phalaenopsis. Phytopathol. Z 71:257-269.

Lesemann, D. E., and S. Doraiswamy. 1975. Bullet-shaped virus-like particles in chlorotic and necrotic leaf lesions of orchids. Phytopathol. Z 83:27-39.

Lesemann, D. E., and R. Marwitz. 1983. Krankenheiten, die durch Viren verursacht werden. P. 595-622, in:

Schlechter, R. Die Orchidean. Vol. 2, F. G. Brieger, R. Maatsch, and K. Senghas, eds. Paul Parey, Berlin.

Lin, N.-S. 1984. Gold-IgG complexes improve the detection and identification of viruses in leaf dip preparations. J. Virol. Methods 8:181-190.

Lin, N.-S., and W. G. Langenberg. 1983. Immunohistochemical localization of barley stripe mosaic virions in infected wheat cells. J. Ultrastruct. Res. $84: 16-23$.

Louro, D., and D. E. Lesemann. 1984. Use of protein A-gold complex for specific labelling of antibodies bound to plant viruses. I. Viral antigens in suspensions. J. Virol. Methods 9:107-122.

Martelli, G. P., and M. Russo. 1981. The fine structure of Cymbidium ringspot virus in host tissues. I. Electron microscopy of systemic infections. J. Ultrastruct. Res. 77:93-104.

Martelli, G. P., and M. Russo. 1984. Use of thin sectioning for visualization and identification of plant viruses. P. 143-223, in: Methods in Virology. Vol. 8, $\mathrm{K}$. Maramorosch and H. Koprowski, eds. Academic Press, New York. 
Matthews, R. E. F. 1982. Classification and Nomenclature of Viruses. S. Karger, Medical and Scientific Pub., New York. $199 \mathrm{pp}$.

Miller, T. J., and H. D. Stone. 1978. The rapid isolation of ribonuclease-free immunoglobulin G by protein Asepharose affinity chromatography. J. Immunol. Methods 24:111-125.

Muller, L. L., and T. J. Jacks. 1975. Rapid chemical dehydration of samples for electron microscopic examinations. J. Histochem. Cytochem. 23:107-110.

Mumford, O. L., and W. R. Thornley. 1977. Location of curly top virus antigen in bean, sugarbeet, tobacco, and tomato by fluorescent antibody staining. Phytopathology $67: 1313-1316$.

Newman, G. R., and B. Jasani. 1984. Post-embedding immunoenzyme techniques. P. 53-70, in: Immunolabelling for Electron Microscopy. J.M. Polak and I. M. Varndell, eds. Elsevier Science Pub. Co. Inc., New York.

Nilsen, R., H. Dalen, and J. Roli. 1982. A procedure for select-ing specific areas of sections for comparative light and electron microscopic studies. J. Microscopy $128: 193-197$.

Nishiguchi, M., F. Motoyoshi, and N. Oshima. 1980. Further investigation of a temperature-sensitive strain of tobacco mosaic virus: its behavior in tomato leaf epidermis. J. Gen. Virol. 46:497-500.

Perrie, W. T., and D. M. Webb. 1982. The correlation of light and electron microscope observations. J. Microscopy $130: 73-77$.

Petzold, H. 1971. Der elektronenmikroskopische Nachweis eines bazilliformen Virus an blattfleckenkranken Dendrobien. Phytopathol. Z 70:43-52.

Purcifull, D. E., and D. L. Batchelor. 1977. Immunodiffusion tests with sodium dodecyl sulfate (SDS) treated plant viruses and plant viral inclusions. Fla. Agr. Exp. Sta. Tech. Bull. 788. 39 pp.

Purcifull, D. E., and J. R. Edwardson. 1981. Potexviruses. P. 627-693, in: Handbook of Plant Virus Infections. E. Kurstak, ed. Elsevier/North Holland Biomedical Press, Amsterdam. 
Rao, D. V., P. Shukla, and C. Hiruki. 1978. In situ reaction of clover yellow mosaic virus (CYMV) inclusion bodies with fluorescent antibodies to CYMV. Phytopathology $68: 1156-1159$.

Robertson, W. M., and I. M. Roberts. 1971. A simple device for the bulk staining and storage of ultrathin sections on grids. J. Microscopy 95:425-428.

Rossi, G. G., B. Pauli, H. Luginbuehl, and D. Probst. 1972. Demonstration by electron microscopy of viruses in cells found by light microscopy to contain inclusion bodies. Path. Microbiol. 38:321-332.

Roth, J. 1983. The colloidal gold marker system for light and electron microscopic cytochemistry. P. 217-284, in: Techniques in Immunocytochemistry Vol. 2, G. R. Bullock and P. Petrusz, eds. Academic Press, New York.

Roth, J. 1984. The protein A-gold technique for antigen localization in tissue sections by light and electron microscopy. P. 113-121, in: Immunolabelling for Electron Microscopy. J. M. Polak and I. M. Varndell, eds. Elsevier Science Pub. Co. Inc., New York.

Russo, M., and G. P. Martelli. 1973. The fine structure of Nicotiana glutinosa $\mathrm{L}$. cells infected with two viruses. Phytopathol. Medit. 12:54-60.

Russo, M., and G. P. Martelli. 1981. The fine structure of Cymbidium ringspot virus in host tissues. II. Light and electron microscopy of localized infections. J. Ultrastruct. Res. 77:105-118.

Russo, M., M. A. Castellano, and G. P. Martelli. 1982. The ultrastructure of broad bean stain and broad bean true mosaic virus infections. J. Submicrosc. Cytol. 14:149160 .

Sheehan, T. J. 1980. Orchids. P. 133-164, in: Introduction to Floriculture. R. A. Larson, ed. Academic Press, New York.

Spurr, A. R. 1969. A low viscosity epoxy resin embedding medium for electron microscopy. J. Ultrastruct. Res. $26: 31-43$.

Wisler, G. C., F. W. Zettler, and D. E. Purcifull. 1982. A serodiagnostic technique for detecting Cymbidium mosaic and Odontoglossum ringspot viruses. Phytopathology $72: 835-837$. 
Wisler, G. C., and F. W. Zettler. In press. Principles and applications of diagnostic techniques used for orchid virus detection. Proc. Eleventh World Orchid Conference, Miami, Fla. 5-12 March 1984.

Zettler, F.W., and M. M. Abo El-Nil. 1977. Bean yellow mosaic infections of gladiolus in Florida. Plant Dis. Reptr. 61: 243-247.

Zettler, F. W., G. R. Hennen, W. H. Bodnaruk, Jr., H. T. Clifford, and T. J. Sheehan. 1978. Wild and cultivated orchids surveyed in Florida for the Cymbiaium mosaic and odontoglossum ringspot viruses. Plant Dis. Reptr. $62: 949-952$.

Zettler, F. W., G. C. Wisler, T. J. Sheehan, N.-J. Ko, and A. E. Logan. 1984. Viruses--Some basics and a perspective for orchid growers. Amer. Orchid Soc. Bull. 53:505-511. 


\section{BIOGRAPHICAL SKETCH}

Nan-Jing Ko was born in Changhwa, Taiwan, on November 5, 1948. He received his primary and secondary education at the Sanchuan Elementary and Changhwa Junior and Senior High Schools, Changhwa. In 1971 he obtained a Bachelor of Science degree in plant pathology from the Plant Pathology Department, National Chung Hsing University at Taichung. After two years' military service as a second Lieutenant, he returned to the Plant Pathology Department of the National Chung Hsing University where he earned his Master of Science degree in 1977. He received a one-year fellowship from the National science Council of the Republic of China from August 1979 to July 1980, of which he spent seven months at the ohio state University and five months at the University of Florida. During that time, he worked with Dr. O. E. Bradfute and Dr. J. R. Edwardson, respectively. In 1982 he received a two-year fellowship from the National Science Council of the Republic of China. In January 1983 he entered the University of Florida to continue work towaras a Doctor of Philosophy degree in plant pathology. He is an associate professor in the Plant Pathology Department of the National Chung Hsing University. After graduation he will continue in his current position at the National Chung Hsing University, Taiwan. 
I certify that I have read this study and that in my opinion it conforms to acceptable standards of scholarly presentation and is fully adequate, in scopoland quality, as a dissertation for the degree of Doctor of PAil ibsophy.

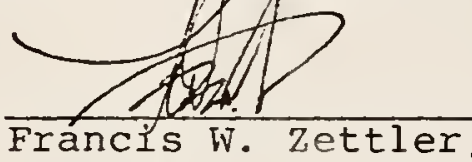
Professor of Plant Pathology

I certify that I have read this study and that in my opinion it conforms to acceptable standards of scholarly presentation and is fully adequate, in scope and quality, as a dissertation for the decree of Doctor of Philosophy.

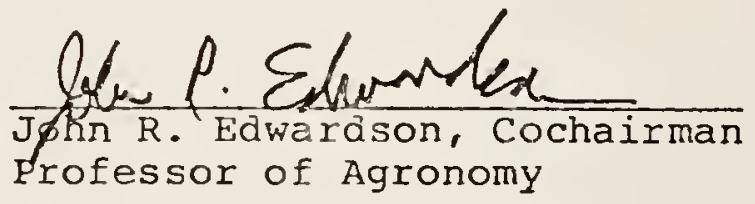

I certify that I have read this study and that in my opinion it conforms to acceptable standards of scholarly presentation and is fully adequate, in scope and quality, as a dissertation for the degree of Doctor of Philosophy.

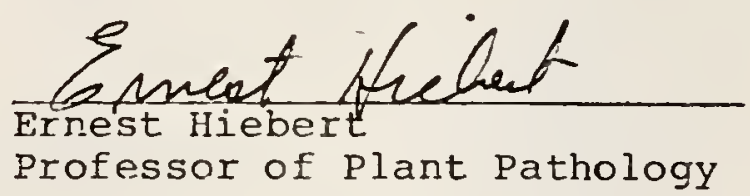

I certify that I have read this study and that in my opinion it conforms to acceptable standards of scholarly presentation ana is fully adequate, in scope and quality, as a dissertation for the degree of Doctor of Philosophy.

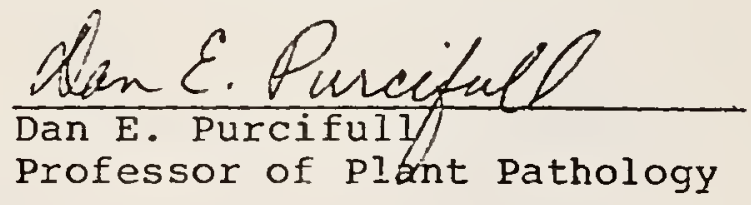

I certify that I have read this study and that in my opinion it conforms to acceptable standards of scholarly presentation and is fully adequate, in scope and quality, as a dissertation for the degree of Doctor of Philosophy.

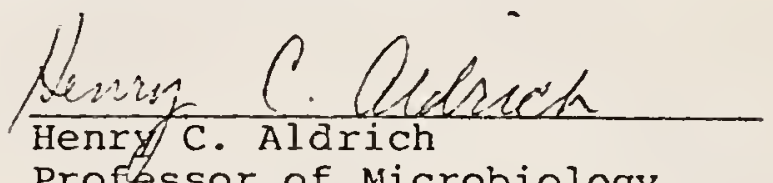
Professor of Microbiology and Cell science 
I certify that I have read this study and that in my opinion it conforms to acceptable standards of scholarly presentation and is fully adequate, in scope and quality, as a dissertation for the degree of Doctor of Philosophy.

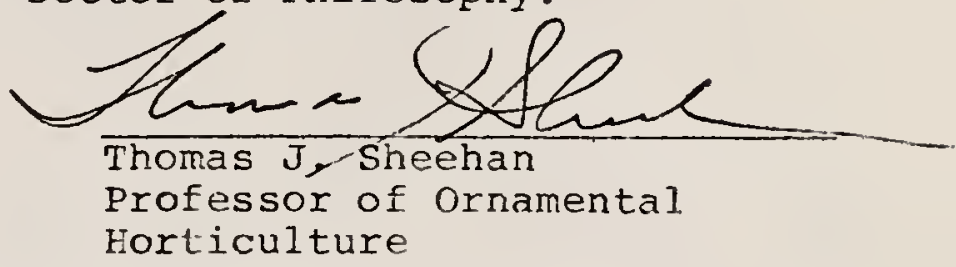

This dissertation was submitted to the Graduate Faculty of the College of Agriculture and to the Graduate School and was accepted as partial fulfillment of the requirements for the degree of Doctor of Philosophy.

May 1985

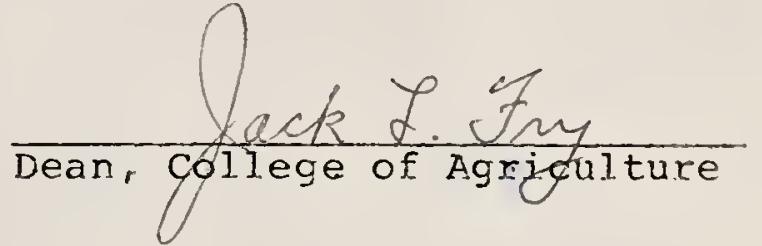

Dean for Graduate studies and Research 
UNIVERSITY OF FLORIDA

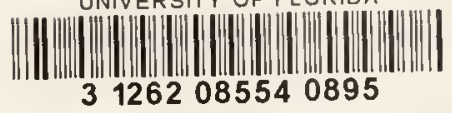

